\section{Treazzano di Monsampolo, a Recent Bronze Age Settlement in the Middle Adriatic Area}

\author{
Annalisa Rumolo
}

\begin{abstract}
Treazzano di Monsampolo is situated in the basin of the Tronto River in the Marche region, central-eastern Italy. In 1979, the site was investigated by the Soprinendenza Archeologica delle Marche through explorative trenches following the fortuitous discovery of a Mycenaean fine ware fragment, which constituted the first Aegean artefact from the region. The excavation, whose documentation has been lost, brought to light evidence of structures related to a settlement. The findings, which mainly include pottery but also animal bones, lithic and bronze fragments as well as evidence of an antler industry, date to a period comprising the end of Middle Bronze Age 3 (MBA 3) and the very beginning of the Final Bronze Age (FBA) $\left(14^{\text {th }}-12^{\text {th }}\right.$ century $\left.\mathrm{BC}\right)$. Except for a few decorated fragments belonging to the Apennine facies, most of the pottery from Treazzano di Monsampolo shows Subapennine typical features, sometimes characterized by regional or local elements. Although the pottery does not show marked influences from the Terramare area, some evidence of these contacts can be seen in the antler industry quite well represented at the site.
\end{abstract}

\section{Keywords}

Treazzano di Monsampolo, Marche, Tronto River, Adriatic Sea, Italy, Subapennine facies, Recent Bronze Age, Mycenaean pottery.

Zusammenfassung - Treazzano di Monsampolo, eine bronzezeitliche Siedlung im mitteladriatischen Raum

Im Jahr 1979 wurde der Fundort Treazzano di Monsampolo (Region Marken, östliches Zentralitalien) von der Soprintendenza Archeologica delle Marche mit Hilfe von Testschnitten untersucht, nachdem ein Fragment mykenischer Feinkeramik entdeckt worden war, das das erste ägäische Artefakt der Region darstellte. Bei der Ausgrabung, deren Dokumentation unglücklicherweise verloren ist, wurden Spuren von Baubefunden einer Siedlung aus der Bronzezeit freigelegt. Die beweglichen Funde - hauptsächlich Keramik, aber auch Tierknochen, Stein- und Bronzefragmente sowie Geweihartefakte - haben einen Datierungsrahmen, der vom Ende der Mittelbronzezeit (MBZ 3) bis zum Beginn der Endbronzezeit (EBZ) reicht (14.-12. Jh. v. Chr.). Obwohl die Keramik nur wenige Einflüsse aus dem Gebiet der Terramare-Kultur in der Poebene aufweist, sind einige Belege für diese Kontakte unter den Geweihartefakten zu finden, die an diesem Fundort gut belegt sind.

\section{Schlüsselbegriffe}

Treazzano di Monsampolo, Marken, Tronto, Adriatisches Meer, Italien, subapenninische Fazies, Bronzezeit, mykenische Keramik.

\section{Introduction}

The Tronto is a $115 \mathrm{~km}$-long river representing the most important waterway of the Marche region in middle Adriatic Italy. Its basin is characterized by the presence of two geographically distinct landscapes: the upper valley to the west and the middle and lower valley to the east. In the upper valley, the river runs through the Sibillini Mountains to the north and the Monti della Laga to the south. The lower valley presents, on the one hand, flatlands, which become progressively wider as they reach the river mouth, and on the other hand, hills close to the coast.

Because of the favourable geo-morphological conformation of the territory, human presence is continuously attested from the Paleolithic period to Roman times. ${ }^{1}$ The findings are quite frequent for the Roman age, while the preand protohistoric periods are underrepresented. Nora Lucentini assumed that this diversification might not depend on the greater occupation in historical times, but that it is related to the modern farming techniques introduced in the 1960s, which involved the use of mechanical tools, destroying the weak pre- and protohistoric traces, which were certainly more fragile than Roman ones. ${ }^{2}$ The archaeological evidence dating back from the period of the Neolithic to the Middle Bronze Age is rather rare. The Recent Bronze Age (RBA), relative to its chronological duration, is more attested, although very few sites have been excavated or intensively investigated. The map (Fig. 1) shows the main RBA sites

\footnotetext{
1 Giorgi, Lucentini 2007, 9-17.

2 Lucentini 1995, 17-48.
} 


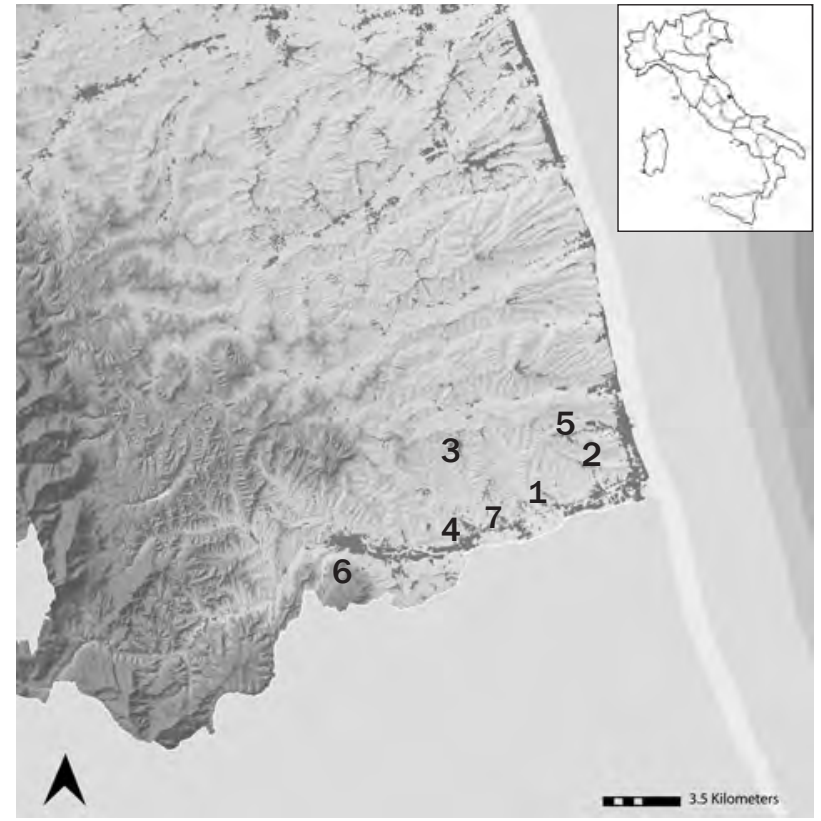

Fig. 1. Distribution map of the RBA sites in the area around the Tronto River. - 1. Treazzano di Monsampolo. - 2. Monteprandone. -3. Offida. - 4. Castel di Lama. - 5. Laferola di Acquaviva Picena. 6. Castel Trosino. - 7. Casale Superiore presso Colli del Tronto.

identified in the surroundings of the Tronto River. Almost all of them are settlements occupying hill plateaus with good drainage systems and without natural borders constraining their extension. Moreover, it seems that they were fairly close to each other, the average distance between the sites being about $2.5-3 \mathrm{~km}^{3}$

The RBA settlements in this part of the region seem to flourish alongside the future route of the Via Salaria. ${ }^{4}$ Their position might suggest the existence of a regular network of contacts and trades. This network probably involved the northern part of the peninsula (Terramare Culture) and the Aegean world.

\section{Discovery and Excavation of the Site}

The archaeological site of Treazzano di Monsampolo was identified during the sixties by the members of the local 'Archaeoclub' of Castel di Lama. On the southern slopes of a small hill on the left of a natural spring called Fiobbo, they collected numerous fragments of Bronze Age impasto pottery and a small sherd (about $3 \mathrm{~cm}$ ) of Mycenaean fine ware pottery decorated with floral motifs (Fig. 2). The discovery of this latter had great relevance since it was the first Aegean artefact found in the Marche region.

3 Cocchi Genick 1996, 202.

4 Lucentini 1987, 444.

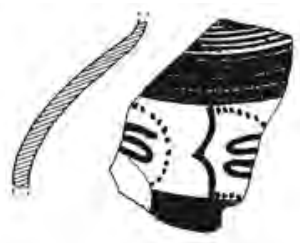

Fig. 2. Mycenaean pottery fragment from Treazzano di Monsampolo (1:1) (LolLini 1982, Pl. LXXIV).

In 1979, the Soprintendenza Archeologica delle Marche authorized and carried out the excavation of the site. ${ }^{5}$ The first archaeological exploration of the area, executed through an elongated trench named A, was restricted to the eastern part of the plain. The archaeological layers were deeply plough-damaged (about $1.10 \mathrm{~m}$ in depth). After the removal of the reshuffled soil, the trench was divided into nine sections. All of them were rich in ash and provided a copious amount of impasto ware belonging to the Subapennine facies, bones and a few pieces of bronze. The typology of the pottery shapes - mainly cups, bowls and jugs - left no doubt about the residential function of the site. In the second section three postholes, five huge stones in situ and clear evidence of a beaten earth floor were identified. ${ }^{6}$ In the western part, not affected by the ploughing, another trench called B (Fig. 3) was excavated. Trench B contained a large amount of pottery belonging to the same chronological horizon as that collected in trench A.?

\section{Chronotypological Interpretation of the Pottery}

The pottery from Treazzano di Monsampolo appears highly fragmented. Among 21,861 sherds collected, 4999 pieces have been classified as diagnostic. Only $30 \%$ of the fragments measured more than $10 \mathrm{~cm}$ (major axis length). The most represented category of vessels is constituted by

5 Unfortunately, none of the reports and documentation drawn up during the digging are available because they were partially lost. The data relative to the excavation mentioned in the paragraph have been reconstructed through photographic dossiers stored in the Soprintendenza delle Marche archives and the short bibliographic information recorded by FORNARINI 1979. Neither the size of the trenches nor the extension of the settlement could be estimated.

6 Fornarini 1979, 314-315.

7 The materials collected during the excavation are stored in the Archaeological Museum of Ascoli Piceno. The tags placed on the boxes suggested the presence of other trenches (C, XIX, XXV, XXVII). The extension, the depth and even the position of these trenches are not clear. However, they provide very little archaeological evidence in comparison with trenches $\mathrm{A}$ and $\mathrm{B}$. 


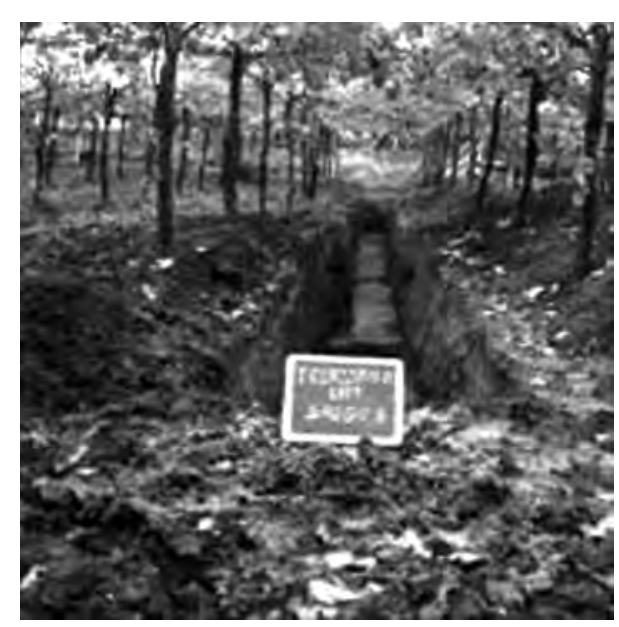

Fig. 3. Treazzano di Monsampolo, Trench B (Photo: D. Lollini; Soprintendenza Archeologica delle Marche archive). Unfortunately, most of the excavation documentation was lost, only a few photos in low quality have been preserved.

jars (33\%), followed by cups $(29 \%)$ and bowls $(29 \%) .{ }^{8}$ The lack of stratigraphic data and detailed documentation about the excavation prevent different occupation phases of the settlement being identified. However, the typological study of the pottery (Tab. 1) has attested a continuous occupation which covers the Recent Bronze Age (therefore both RBA 1 and RBA 2) up to the very beginning of the Final Bronze Age (FBA). Only 30 sherds with incised and impressed Apennine decorations seem to belong to a more ancient chronological horizon (Middle Bronze Age 3 - MBA 3). The widespread Apennine motif is the checkerboard pattern with alternately free and carved squares (Pl. 1/A). ${ }^{9}$ This decoration is found at numerous Adriatic sites in central (e.g. Castel Trosino) and southern Italy (e.g. Coppa Nevigata). ${ }^{10}$ At Coppa Nevigata, this motif occurs in association with pottery dating back to the first phase of the RBA. ${ }^{11}$ The carved lines are another Apennine motif fairly well attested at Treazzano di Monsampolo (Pl. 1/B). ${ }^{12}$ Only a few fragments present grooved (Pl. 1/C1-3) or impressed

8 The statistic is based on all the diagnostic fragments found at the site. Such quantitative data are slightly different taking into consideration only rims ( $40 \%$ cups, $31 \%$ jars and $20 \%$ bowls).

9 Macchiarola 1987, motif 165A.

10 Cf. Polletti 2000, Figs. 29, 4. - Cazzella, Recchia 2012, Pl. 11/9.

11 The issue regarding the persistence or the absence of Apennine decorations in the RBA contexts is still unsolved, especially for a multilayered site such as Coppa Nevigata.

12 Macchiarola 1987, motif 126. decoration (Pl.1/D1). Regarding the open shapes, at Treazzano di Monsampolo two main forms have been identified: the bowls and the cups.

\subsection{Bowls}

The bowls have been organized into ten sub-groups, according to shape and type. Type A1 is constituted by bowls with an enlarged oblique lip and internal edge (Pl. 1/E). This type is usually found in MBA 3 and RBA 1 contexts. ${ }^{13}$ Two specimens had a preserved triangular lug on the lip (Pls. 1/ E1, 1/E4). Articulated bowls presenting shallow angular-profile basins and oblique rims with an internal edge, as the type A2, are often associated with RBA 2 sites (Pl. 1/F). Sometimes, as in the specimen from Treazzano di Monsampolo, the rim is decorated with vertical grooves on the interior part. ${ }^{14}$

The family of truncated conical bowls is widely represented and differentiated into three groups based on their size and decoration: A3, A6, A7 (Pls. 2/B, 3/A). Type A3 is particularly attested in central Italy during the MBA and RBA; it comprises medium-sized truncated conical bowls decorated with a straight plastic cordon close to the rim (Pl. 2/B1-2). ${ }^{15}$ The types A6 and A7 include large bowls characterized by a deep basin. Type A6 has a slightly convex profile with a flat rim and one or two plastic cordons on the body (Pls. 2/B3-5, 3/A1);16 type A7 is marked by a short rim forming a slight concavity with the considerably convex body below (Pl. 3/A2-3). ${ }^{17}$

The semiglobular bowls with a non-articulated profile (Pl.2/A) are rather numerous. They have been divided in two sub-groups: the types A4 and A5, characterized by different shapes of the rim. Type A4 with a rounded or semi-rounded rim is a form with long continuity of use (from the MBA to the advanced RBA) and wide distribution (Pl. 2/A1-4). Similar bowls have been found throughout Italy. ${ }^{18}$ Type A5 is distinguished by a concave rim (Pl. 2/A5-7). Its distribution mainly concerns the internal and coastal zones of the Adriatic region. ${ }^{19}$ One of the specimens from Treazzano di Monsampolo has a vertical handle designed as a head with

\footnotetext{
13 Damiani 1991, Pl. 58/1.

14 Cf. Andreotti, Zanini 1995-1996, Pl. 6/2.

15 Cf. Belardelli 2004, Fig. 2/2. - Gonzalez Muro, Maini, MaZZARI 2010, Fig. 28/4.

16 Cf. Moscoloni, Danesi, Galluzzi 2007, Fig. 2/8.

17 Cf. Di Fraia, Grifoni Cremonesi 1996, Fig. 53/2.

18 Cf. Bernabò Brea, Cavalier 1980, Fig. 106/c. - Salzani 1994, Pl. II/4. - Cazzella, Recchia 2012, Pl. 20/6.

19 Cf. De Grossi Mazzorin 1976, Pl. 18/1. - Cazzella et al. 2007, Fig. 5/5. - Damiani 2010, Fig. 6B/2.
} 
eyes made of small lateral horns (Pl. 2/A6). This variety is well known in central and southern Italy and dates to an advanced phase of the RBA. ${ }^{20}$

The family of the bowls found at Treazzano di Monsampolo also includes the types A8 and A9 (Pl. 3/B) marked by a shallow basin. Type A8 presents an everted external rim and convex profile (P1. 3/B1). This kind of bowl is usually characterized by different stylized handles. The specimen from Treazzano di Monsampolo has a bilateral-head knob on the rim. A similar attribute appears on a sample coming from Grotta S. Angelo sulla Montagna dei Fiori. ${ }^{21}$ Type A9 is very common in RBA middle Adriatic archaeological contexts, although comparable bowls with a softly flaring rim and slightly convex profile already appear in middle Tyrrhenian sites during the MBA. The specimen from Treazzano di Monsampolo (P1. 3/B2) has extremely strong parallels with bowls found in the South Marche region. ${ }^{22}$ Type A10 is represented by a shallow basin characterized by an external rim and almost straight profile (Pl.3/C1). This shape is very common and its diffusion rather wide.

\subsection{Cups}

Cups are widely attested at Treazzano di Monsampolo. Among the huge family of cups, five main forms have been recognized, each of them containing different variants. The largest type includes carinated cups (Pls. 4, 5/A), which have a rather long continuity of use covering almost all of the protohistoric period. At Treazzano di Monsampolo, type B1 is characterized by a slight concavity between the rim and the body below (Pl. 4). This type is quite common from the MBA to RBA 2. ${ }^{23}$ The B1A variety presents a vaguely concave body between the indistinct rim and the rounded carination (Pl. 4/A). The closest parallels for this form come from the Terramare territory in the Po Plain ${ }^{24}$ and central Italy. ${ }^{25}$ To the B1B variety belongs a series of carinated cups, often characterized by a flaring rim, with a slightly concave body and deep basin (Pl. 4/B). The specimens compare particularly well with some carinated cups found in Coppa Nevigata RBA 2 layers ${ }^{26}$ and in the Marche region. ${ }^{27}$ Carinated cups with a rather concave profile and

20 Cf. Belardelli 2004, Pl. LXII/7.

21 Cf. Di Fraia, Grifoni Cremonesi 1996, Fig. 57/4.

22 Cf. Damiani 2010, Pl. 16/A1.

23 Damiani 2010, 176-208.

24 Cf. Massi Pasi, Stoppioni 1988, Fig. 166/56.

25 Cf. De Grossi Mazzorin 1976, Pl. 16/2. - Di Fraia, Grifoni Cremonesi 1996, Fig. 67/6. - Ialongo 2007, Fig. 84/18.

26 Cf. Puglisi 1982, Pl. VI/1. - Cazzella, Moscoloni 1988, Figs. 6/13; 7/5. - Cazzella, Recchia 2012, Pl. 24/12.

27 Cf. De Grossi Mazzorin 1976, Pl. 17/3. - Damiani 2010, Pl. 16/4. short flaring rim have been grouped in the B1C variety (Pl. 4/C) and could be easily assimilated with similar samples coming from RBA 1 sites in north-central Italy. ${ }^{28}$ The variety $\mathrm{B} 1 \mathrm{D}$ is represented by carinated cups with a concave profile and pronouncedly flaring rim (Pls. 4/D, 5/A). The chronology of this vessel covers all the RBA, even if it is more attested in RBA 1. The geographical diffusion comprises both the middle Adriatic and the middle Tyrrhenian areas. ${ }^{29}$ Comparable specimens to those from Treazzano di Monsampolo are found especially in Marche ${ }^{30}$ and Lazio. ${ }^{31}$

The B2, B3, B4 and B5 cup types have a convex profile (Pl. 5/B). Type B2 is characterized by a rim softly distinguished by an internal edge and a deep basin (Pl. 5/B1). The shape, common in the MBA, is also used during the first phase of the RBA and could be compared to a similar cup from Torre Mordillo. ${ }^{32}$ Type B3 is characterized by an indistinct rounded rim with a barely visible carination (Pl. 5/ B2). One cup from Vaccina, different in size, has some resemblance with the specimen from Treazzano di Monsampolo and could be dated to RBA $1 .{ }^{33}$ A fairly shallow basin differentiates the types $\mathrm{B} 4(\mathrm{Pl} .5 / \mathrm{B} 3$ ) and $\mathrm{B} 5(\mathrm{Pl} .5 / \mathrm{B} 4)$ from the other cups. Type B4 is represented by a slightly flaring rim marked by an internal edge (Pl. 5/B3) which found a distant parallel in one vessel coming from the RBA settlement of Vejano. ${ }^{34}$ From the same site comes a carinated cup which has some affinities with the type B5 of Treazzano di Monsampolo, characterized by a rounded carination and a strongly flaring rim (Pl. 5/B4). ${ }^{35}$

\section{Handles}

The cups are usually provided with handles typified by plastic projections. At Treazzano di Monsampolo, the most common plastic handle shows bird-shaped knobs (Pl. 6/A). On the basis of their characteristics, the handles have been allocated to several sub-groups. The shape G1A presents a long, slightly or strongly hooked neck with a beak curved upwards and the forehead marked by a transversal crest (Pl. 6/ A1-7). This category of handles is very widespread during RBA 2 in central and northern Italy. The main comparisons with Treazzano di Monsampolo G1A handles come from

\footnotetext{
28 Cf. Vigliardi 1968, Pl. 6/8. - Damiani 2010, Pl. 46/A4.

29 Damiani 2010, 172.

30 Cf. Damiani 2010, Pls. 5/7; 32/2-7.

31 Cf. Peroni 1959, Pl. 24/7.

32 Cf. Trucco, Vagnetti 2001, Fig. 82/4.

33 Cf. Damiani 2010, Pl. 41/4.

34 Cf. Di Gennaro et al. 2000, Fig. 3/2.

35 Cf. Di Gennaro et al. 2000, Fig. 3/3.
} 
Fontanavecchia di Camerano, ${ }^{36}$ S. Paolina di Filottrano, ${ }^{37}$ Luni sul Mignone, ${ }^{38}$ Scarceta ${ }^{39}$ and S. Giuliano in Toscanella. ${ }^{40}$ Type G1B is a small handle with a horizontal beak, short forehead and thickened neck (Pl.6/A8). The presence of this type is confined to a not advanced RBA phase; its diffusion is mostly concentrated in central Italy. ${ }^{41}$ The specimen from Treazzano di Monsampolo has convincing similarities with an example from Vaccina. ${ }^{42}$ An unconventional bird-shaped handle represents the type G1C characterized by a stylized form without anatomic details (Pl. 6/A10). Isabella Damiani defines this type as a variant of the axe-shaped handle; its distribution mainly relates to the Marche region and its chronology covers the whole RBA. ${ }^{43}$ Another variety of ornitomorphic handles represented at Treazzano di Monsampolo (G1D) is constituted by bird-shaped handles with the head turned towards the interior of the vessel, a vertical crest or intense convexity on the forehead and eyes made with small lateral horns (Pl. 6/B1-4). This type is more attested in RBA 1, although it is considered a long-duration form, also appearing in RBA 2 contexts. ${ }^{44}$ A more stylized birdshaped knob set on a curvilinear strap handle is considered an advanced version of the type and is diffused in RBA 2. The specimen from Treazzano di Monsampolo (Pl. 6/B5) has marked resemblances with a piece from Casale Nuovo dating to the late RBA. ${ }^{45}$ Very interesting is the presence of one exemplar of a bird-shaped knob in a flying position set on a horizontal handle (Pl. 6/A9). This type (G1E) is distinctive of a more recent phase of the RBA; its circulation seems to be limited to the middle and low Adriatic areas. The only exception comes from Lipari, where the type is interpreted in a 'monumental' way. ${ }^{46}$

Less represented at Treazzano di Monsampolo are the horn-shaped knobs (type G2). The still-preserved apexes refer to bovine horns (Pl. 6/C), while in one case a birdshaped appendix without anatomic details has been documented (Pl. 6/C3). ${ }^{47}$ When the connection between the two horns is preserved, it is possible to note a short protuberance interpreted as a muzzle (Pl. 6/C1-2). Among the hornshaped handles found, one specimen has a decoration

36 Cf. Damiani 2010, Pl. 97/6.

37 Cf. Rellini 1932, Pl. VIII/5.

38 Cf. Fugazzola Delpino 1976, Fig. 45/5.

39 Cf. Poggiani Keller 1999, Fig. 45/14.

40 Cf. Pettazzoni 1916, Fig. 14/2.

41 Damiani 2010, 275-279.

42 Cf. Pacciarelli 1979, Fig. 4/3.

43 Damiani 2010, 398-400.

44 Damiani 2010, 293-301.

45 Cf. Angle et al. 1993, Fig. 5/5.

46 Cf. De Grossi Mazzorin 1976, Pl. 22/1. - Damiani 2010, 291.

47 Cf. Lollini 1979, Fig. 8/19. - Damiani 2010, Pl. 112/8. composed of grooves on the trunk and the horn connection and impressed hoops (Pl. 6/C1). ${ }^{48}$

Only one equine-shaped handle (type G3) has been discovered at the site (Pl. 7/A1). It is decorated with carved lines and presents small lateral horns. ${ }^{49}$ The type is not really widespread in the RBA, although it has an extensive distribution which covers both the Adriatic and the Tyrrhenian side. ${ }^{50}$ Bilateral-head knobs set on bowls or cups constitute the type G4 (Pls. 2/A6, 3/B1). They are comparable to specimens found in RBA sites in the middle and south Adriatic areas. ${ }^{51}$ The bilateral-head knob is considered a type of long duration as well as the oblique handles with volutes called 'manici con ripresa' by Damiani. ${ }^{52}$ These particular handles (type G5) are very popular during the MBA, while their diffusion is limited to Lipari and central Italy, especially the Marche region, during the whole RBA. At Treazzano di Monsampolo two specimens have been documented (Pl. 7/ A2-3), both having an oval hole in the middle and apexes with fairly circular sections. Close parallels have been identified with pieces coming from S. Giovenale ${ }^{53}$ and Monteroduni. ${ }^{54}$

Strap (type G6) and tubular (type G7) handles are also represented at Treazzano di Monsampolo (Pl. 7/B). The first ones have a simple form, some of them presenting one or several longitudinal ridges on the external surface (Pl. 7/B1-7). The tubular handles have a smooth surface, sometimes characterized by a central ridge (Pl. 7/B9), corresponding to a shape very widespread in the whole of Italy during the RBA. Some of the tubular handles are decorated with horizontal or vertical grooves (Pl. 7/B8-11). Similar handles have been found in several coeval contexts in central and northern Italy. ${ }^{55}$

\subsection{Jars}

The excavation also brought to light several jars. Six different jar shapes have been identified at the site. Type C1 is characterized by a cylindrical body and flat rim (Pl. 5/C). The diffusion of these jars covers the entire peninsula from

48 Cf. Lucentini 1987, Fig. 7/10. - Damiani, Morico 1996, Pl. 4/C 21.

49 Cf. Bianchi 2004, Fig. 11.

50 Damiani 2010, 369.

51 Cf. Pennacchioni, Persiani 1982, Fig. 1/6. - Di Fraia, Grifoni Cremonesi 1996, Fig. 57/4. - Cazzella, Recchia 2012, Fig. 31/8.

52 Damiani 2010, 402-405.

53 Cf. Gierow 1984, Fig. 10/7.

54 Cf. Cazzella et al. 2007, Fig. 6/15.

55 Bianchi 2004, Fig. 9/14. - Caironi, Guerra, Vaccari 2009, Fig. 9/2. - Cf. Danesi, Galluzzi 2009, Pl. II/6. - Pignocchi, Silvestrini 2015, Fig. 1/7-9. 
the MBA to the FBA. ${ }^{56}$ Sometimes they are decorated with horizontal cordons and interpreted as bowls.

Different-sized jars with an expanded ovoid body and short flaring rim are grouped in type C2 (Pl. 8/A1-4). They have strong parallels with RBA 1 specimens found at Coppa Nevigata ${ }^{57}$ and at Collelongo-Fond'jò. ${ }^{58}$ One of these jars shows an Apennine decoration composed by an incised zigzag pattern and dots (Pl. 8/A3). The shape of the vessel, as well as its decoration, has a strict resemblance with a MBA 3 jar from Coccioli. ${ }^{59}$

The type C2 is quite similar to the type C3 (Pl. 8/A5-6), which is distinguished only by the rim characterized by an internal flex. Most of the analogous vessels come from the middle Adriatic area. ${ }^{60} \mathrm{~A}$ unique specimen from Treazzano di Monsampolo is decorated with impressed circlets and horizontal and oblique incised lines (Pl. 8/A6). The motif is considered typical of the FBA and is a fairly good parallel with a sherd brought to light at Madonna degli Angeli. ${ }^{61}$

The jars belonging to the type $\mathrm{C} 4$ present an expanded flat rim, which is very flaring and characterized by an internal edge (Pl. 8/B). Since this type is only represented by two small fragments of rim, it is not possible to define exactly the form of the body below, which is probably ovoid. Based solely on the rim shape, the specimens from Treazzano di Monsampolo match with jars which were quite widespread in the whole RBA that are mainly attested in central Italy. ${ }^{62}$ Some vessels with a distinct concave neck have also been included in the huge family of the jars (Pl. 8/C). Their frequency is quite high in MBA 3 sites, especially in southern Italy, although their production probably continued during the first phase of the RBA. ${ }^{63}$

Two vessels with beak handles (Pl. 9/B1-2) from Treazzano di Monsampolo have also been classified as jars. This type (C6) is more attested on the central and southern Adriatic coast and relatively uncommon in coeval Tyrrhenian contexts. Renato Peroni dated this type to the whole RBA period, while Damiani assumes that its production was restricted to RBA $1 .^{64}$

56 Cf. Mieli, D’Ercole, Cosentino 2003, Fig. 5. - Damiani 2010, Fig. 47/7. - Cazzella, Recchia 2012, Fig. 26/10.

57 Cf. Cazzella, Moscoloni 1988, Fig. 2/15.

58 Cf. GATTi 2004, Fig. 54/7.

59 Cf. Macchiarola 1987, Fig. 20/1.

60 Cf. Di Fraia, Grifoni Cremonesi 1996, Fig. 57/8. - Lo Porto 1997, Fig. 42.

61 Cf. Leopardi, De Pompeis 1980, Fig. 5/13.

62 Cf. Di Fraia, Grifoni Cremonesi 1996, Fig. 56/11. - Damiani 2010, Pl. 51/2.

63 Cf. Di Fraia, Grifoni Cremonesi 1996, Fig. 56/9.

64 Damiani 2010, 256-259.

\subsection{Other Forms}

At Treazzano di Monsampolo an open-shape vessel with short beak and articulated rim has also been identified (Pl. 9/ B3). The shape (type E1) is not widespread in the Peninsula; the only specimen which has strong similarities with the one from Treazzano di Monsampolo was found at Fossa Nera and is dated to RBA $2 .{ }^{65}$

A small number of large-dimension vessels (pithoi) were found at the site during the excavation (Pl. 9/A1-2). They are characterized by a quite flaring rim and a more or less marked internal edge (type D). The type is rather popular in central Italy; the strongest resemblance with Treazzano di Monsampolo pithoi has been noted at Vaccina. ${ }^{66}$

Very interesting is the presence of open-shape vessels with an internal ledge (type E2). Usually this kind of jar is typified by a series of bosses or horns on the external surface. ${ }^{67}$ At Treazzano di Monsampolo both the vessels identified for this category have a smooth surface decorated with plastic cordons (Pl. 9/C1-2). The internal ledge was most likely used to hold a lid.

Several types of lids have been identified (P1. 9/D). The lids belonging to the type $\mathrm{F} 1$ have a truncated conical shape, rounded lip and horizontal or vertical plastic cordons (Pl. 9/ D1-3). This shape is very common, particularly in central Italy, and largely attested during the RBA and FBA. ${ }^{68}$ Other lids (type F2) are characterized by a rounded form, with or without a horizontal handle (Pl. 9/D4-6). In this case again, the closest parallels come from central Italy ${ }^{69}$

Besides the numerous vessels mentioned above, the site has provided a copious amount of plaster, some stoves (Pl. 10/C) and both disc-shaped and biconical spindle whorls (Pl. 10/B). All these materials leave no doubt about the function of the site, which was clearly a settlement.

Among the pottery three small zoomorphic figurines (Pl. 10/A) have been identified, probably representing horses (one head and two quadruped bodies are preserved). The discovery of these figurines is really interesting because of their limited presence in southern and central Italy. Besides the middle Adriatic coast, zoomorphic figures have only been identified at Campomarino, ${ }^{70}$ Madonna degli Angeli, ${ }^{71}$ Moscosi di Cingoli ${ }^{72}$ and Colle dei Cappuccini. ${ }^{73}$ By

65 Cf. Andreotti, Zanini 1995-1996, Pl. 7/9.

66 Cf. Damiani 2010, Pl. 52/15.

67 Cf. Damiani 2010, Pl. 11/3.

68 Cf. Fratini 1997, Pl. XV/8. - Ialongo 2007, Fig. 18/1.

69 Cf. Damiani 2010, Fig. 9/1.

70 Di Niro 1991, 47.

71 Leopardi, De Pompeis 1980, 32.

72 Silvestrini, Pignocchi 1997, 160.

73 Lollini 1959, 52. 

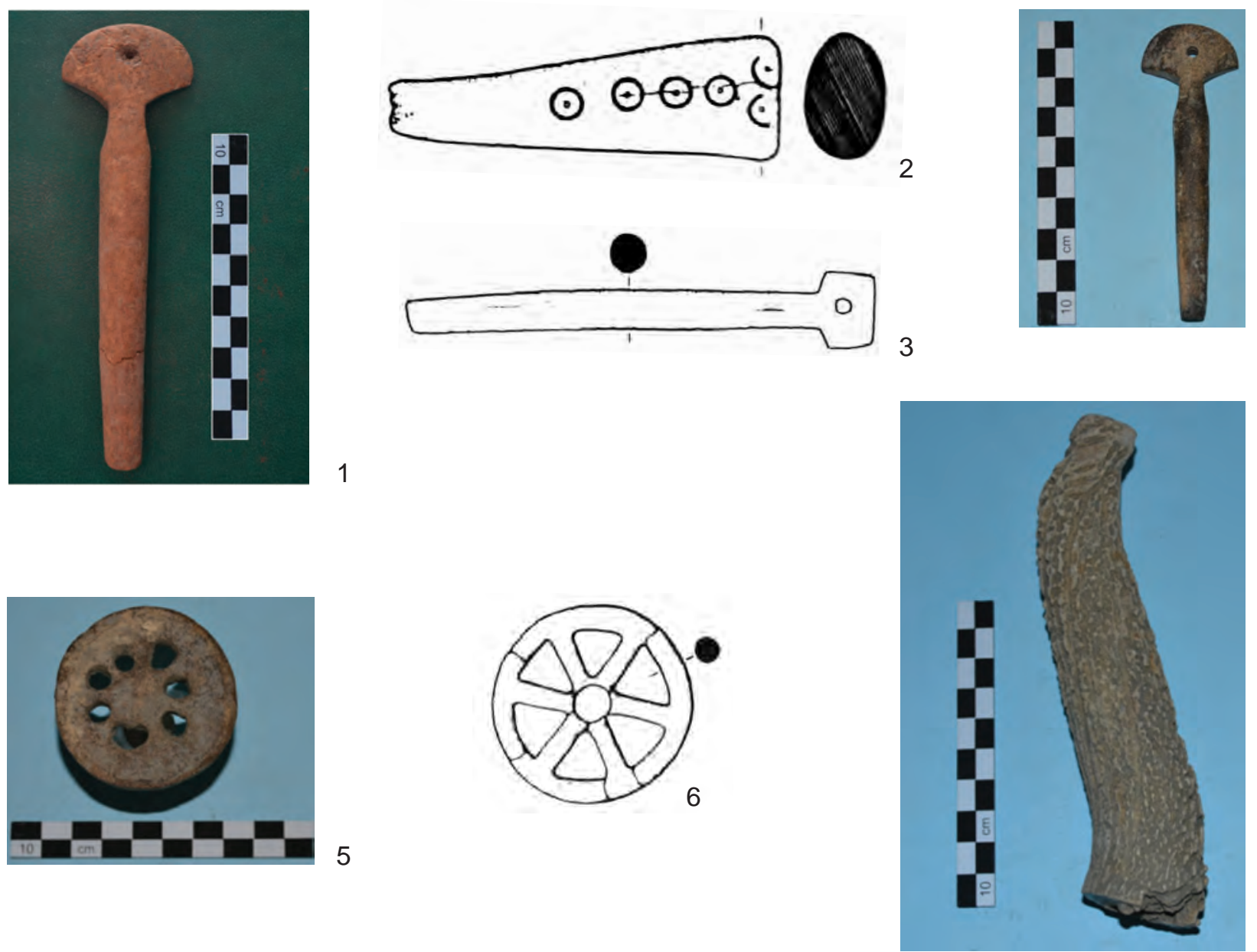

Fig. 4. Bone and antler industry (Photos: A. Rumolo, drawings: LolLini 1982, Pl. LXXIII).

contrast, this form of manufacture is quite widespread in northern Italy during the end of the MBA and the FBA. ${ }^{74}$

\section{The Antler Industry}

At Treazzano di Monsampolo the antler industry is represented by few artefacts (Fig. 4), which are comparable with specimens coming from both central and northern Italy. The excavation has brought to light several awl handles (Fig. 4/1-4). The specimens found at Treazzano di Monsampolo mainly belong to two types: the one with a straight simple handle (Fig. 4/2) and the one with a flat-shaped head (Figs. 4/1, 4/3-4). Both the types are well-known in the Terramare region and rather widespread along the northern Adriatic coast during the MBA and the RBA. ${ }^{75}$ The simple awl handles, usually decorated with incised circles

74 Bernabò Brea, Cremaschi 1995, 309-323. - Bianchi 2004, 411485. - Damiani 2010, 11-21.

75 BIANCHI 2004, 473.
(Fig. 4/2), are more attested in the Emilia Romagna region ${ }^{76}$ although some specimens have been found in the Veneto ${ }^{77}$ and South Marche ${ }^{78}$ areas. The most common awl handle in the area between Terramare and the Marche region is the type with a shaped head. It was probably used for holding fine bits with a circular section and shows a certain variability in the shape of the head. The three awl handles with a shaped head from Treazzano di Monsampolo are extremely well made with a smooth surface, straight body and a circular hole in the middle of the head. While two specimens have globular heads (Figs. 4/1,4/4), another one (Fig. 4/3) is characterized by a small quadrangular end. All the awl handles from Treazzano di Monsampolo are dated to the RBA based on their similarities with specimens found at Santa Rosa di

76 Provenzano 1997, 524-544.

77 Salzani 2014, Pl. 3/6.

78 De Grossi Mazzorin 1976, Pl. 20/4. 


\begin{tabular}{|c|c|c|c|c|}
\hline Family & Type & Brief description of the main characteristics & Chronology & Plate \\
\hline \multirow{10}{*}{ 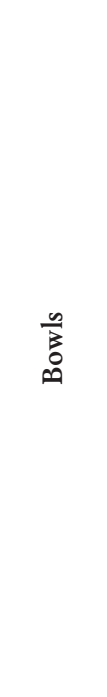 } & A1 & $\begin{array}{l}\text { Enlarged oblique rim with internal edge } \\
\text { (sometimes with triangular lugs). }\end{array}$ & MBA3 - RBA1 & $1 / \mathrm{E}$ \\
\hline & A2 & $\begin{array}{l}\text { Oblique rim with internal edge and shallow angular profile of the basin } \\
\text { below. }\end{array}$ & RBA2 & $1 / \mathrm{F}$ \\
\hline & A3 & Truncated conical body decorated with plastic cordons close to the rim. & $\mathrm{MBA}-\mathrm{RBA}$ & 2/B1-2 \\
\hline & A4 & Rounded or semi-rounded rim and cap-shaped body. & $\mathrm{MBA}-\mathrm{RBA}$ & 2/A1-4 \\
\hline & A5 & Rounded concave rim and cap-shaped body. & RBA2 & 2/A5-7 \\
\hline & A6 & $\begin{array}{l}\text { Flat rim and slightly convex profile of the body underneath usually } \\
\text { decorated with one or two plastic cordons. }\end{array}$ & $\mathrm{RBA}-\mathrm{FBA}$ & $\begin{array}{c}2 / \mathrm{B} 3-5 \\
3 / \mathrm{A} 1\end{array}$ \\
\hline & A7 & $\begin{array}{l}\text { Short rim forming a slight concavity with the considerably convex body } \\
\text { below. }\end{array}$ & $\mathrm{RBA}-\mathrm{FBA}$ & $3 / \mathrm{A} 2-3$ \\
\hline & A8 & Everted external rim and convex profile of the body below. & RBA & 3/B1 \\
\hline & A9 & Slightly flaring rim and convex profile of the body below. & $\mathrm{MBA}-\mathrm{RBA}$ & 3/B2 \\
\hline & A10 & External rim and almost straight profile. & $\mathrm{MBA}-\mathrm{RBA}$ & 3/C1 \\
\hline \multirow{5}{*}{ 产 } & B1 & $\begin{array}{l}\text { Slight concavity between the rim and the body below. } \\
\text { Varieties: } \\
\text { - B1A: indistinct rim and concave body underneath with rounded } \\
\text { carination; } \\
\text { - B1B: flaring rim and slightly concave body underneath characterized } \\
\text { by quite deep basin; } \\
\text { - B1C: very short flaring rim and concave profile of the body } \\
\text { underneath characterized by a marked carination; } \\
\text { - B1D: extensive flaring rim and concave profile of the body } \\
\text { underneath. }\end{array}$ & $\mathrm{MBA}-\mathrm{RBA}$ & $\begin{array}{c}4 \\
5 / \mathrm{A}\end{array}$ \\
\hline & B2 & $\begin{array}{l}\text { Rim softly distinguished by an internal edge with deep convex basin } \\
\text { below. }\end{array}$ & $\mathrm{MBA}-\mathrm{RBA}$ & $5 / \mathrm{B} 1$ \\
\hline & B3 & $\begin{array}{l}\text { Indistinct rounded rim with a convex body underneath characterized by } \\
\text { a barely visible carination. }\end{array}$ & RBA1 & $5 / \mathrm{B} 2$ \\
\hline & B4 & Slightly flaring rim marked by an internal edge and convex body below. & RBA & $5 / \mathrm{B} 3$ \\
\hline & B5 & $\begin{array}{l}\text { Strongly flaring rim and convex body characterized by rounded } \\
\text { carination. }\end{array}$ & RBA & $5 / \mathrm{B} 4$ \\
\hline \multirow{6}{*}{$\stackrel{\infty}{\tilde{\Xi}}$} & $\mathrm{C} 1$ & Flat rim and cylindrical body below. & MBA - FBA & $5 / \mathrm{C}$ \\
\hline & $\mathrm{C} 2$ & Short flaring rim and expanded ovoid body below. & MBA - RBA1 & 8/A1-4 \\
\hline & C3 & Rim with internal edge and ovoid body below. & MBA - FBA & 8/A5-6 \\
\hline & $\mathrm{C} 4$ & Expanded flat rim with internal edge and most likely ovoid body. & RBA & $8 / \mathrm{B}$ \\
\hline & $\mathrm{C} 5$ & Flaring rim and distinct concave neck. & MBA3 - RBA & $8 / \mathrm{C}$ \\
\hline & C6 & Flaring rim with beak-handle and concave body. & RBA & 9/B1-2 \\
\hline 泀 & $\mathrm{D}$ & Flaring rim with internal edge and deep basin. & RBA & 9/A \\
\hline
\end{tabular}

Tab. 1. Summary typological table. 


\begin{tabular}{|c|c|c|c|c|}
\hline Family & Type & Brief description of the main characteristics & Chronology & Plate \\
\hline \multirow{2}{*}{ 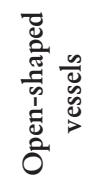 } & E1 & Articulated rounded rim with short beak underneath. & $\mathrm{RBA}$ & 9/B3 \\
\hline & E2 & $\begin{array}{l}\text { Expanded rim and straight body underneath. The inner part is } \\
\text { characterized by a thick ledge. }\end{array}$ & RBA & 9/C1-2 \\
\hline \multirow{2}{*}{$\underbrace{0}_{0}$} & F1 & $\begin{array}{l}\text { Rounded lip and truncated-conical shape. Usually decorated with } \\
\text { horizontal or vertical plastic cordons. }\end{array}$ & $\mathrm{RBA}-\mathrm{FBA}$ & 9/D1-3 \\
\hline & $\mathrm{F} 2$ & Circular shape with or without horizontal handle. & RBA - FBA & 9/D4-6 \\
\hline \multirow{7}{*}{ 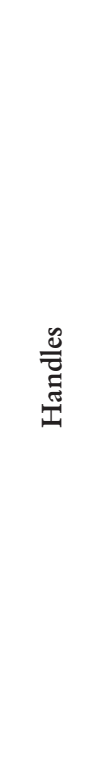 } & G1 & $\begin{array}{l}\text { Bird shaped knobs. } \\
\text { Varieties: } \\
\text { - G1A: head marked by transversal crest, beak curved upwards and } \\
\text { long slightly or strongly hooked neck; } \\
\text { - G1B: short forehead, horizontal beak and thickened neck; } \\
\text { - G1C: external stylized beak without anatomic details; } \\
\text { - G1D: head turned towards the interior of the vessel, vertical crest or } \\
\text { intense convexity on the forehead and eyes made with small lateral } \\
\text { horns; } \\
\text { - G1E: bird in flying position set on a horizontal handle. }\end{array}$ & RBA & $6 / \mathrm{A}-\mathrm{B}$ \\
\hline & G2 & Horn-shaped knobs. & $\mathrm{MBA}-\mathrm{RBA}$ & $6 / \mathrm{C}$ \\
\hline & G3 & Equine-shaped handle. & $\mathrm{RBA}$ & 7/A1 \\
\hline & G4 & Bilateral-head knobs. & RBA & $\begin{array}{l}\text { 2/A6 } \\
3 / \mathrm{B} 1\end{array}$ \\
\hline & G5 & Oblique handles with volutes. & MBA - RBA & 7/A2-3 \\
\hline & G6 & Strap handles with one or several longitudinal ridges. & $\mathrm{MBA}-\mathrm{FBA}$ & 7/B1-7 \\
\hline & G7 & Tubular handles with horizontal or vertical ridges. & RBA & 7/B8-11 \\
\hline
\end{tabular}

Tab. 1. Continued.

Poviglio (Emilia Romagna), ${ }^{79}$ Cerea-Le Vallette (Veneto) ${ }^{80}$ and Moscosi di Cingoli (Marche) ${ }^{81}$

At Treazzano di Monsampolo two antler spoked wheels were also collected (Fig. 4/5-6). One of them has six spokes (Fig. 4/6) and constitutes the most widespread type in the whole of northern and central Italy. This kind of artefact, probably pinheads, is underrepresented in the southern part of the peninsula where the only specimens have been identified at Timmari and Termitito. ${ }^{82}$ The other antler wheel from Treazzano di Monsampolo presents a seven-spoke wheel (Fig. 4/5). The uncommon number of the spokes, together with the absence of a central hole and the rough shape of the cylindrical stalk, suggests that it was

79 Provenzano 1997, 524-544.

80 Salzani 2014, 112-118.

81 Silvestrini, Pignocchi 1997, 155-160.

82 PASQuini 2005, 985-991. unfinished (or a production waste). Although the quantity of antler objects is quite low at Treazzano di Monsampolo, the seven-spoke wheel and the identification of a semiworked horn (Fig. 4/7) seem to show the presence of a local industry.

\section{The Mycenaean Fragment}

As mentioned above, the excavation of Treazzano di Monsampolo was preceded by archaeological surveys during which copious materials were collected. Among them, a small fragment of Mycenaean fine ware pottery decorated with a floral motif was recognized (Fig. 2). Since it constituted the first Mycenaean ceramic vessel from the Marche region, the Soprintendenza Archeologica delle Marche decided to start the exploration of the site. Unfortunately, the excavation did not bring to light any other Mycenaean evidence. However, in the subsequent years, accurate research in the Marche region has shown that the area had a not 
marginal role in the exchange networks connecting Italy to the Aegean. So far, in several sites in the region materials attesting direct or indirect contacts with the Mycenaean culture were found: Montagnolo di Ancona, ${ }^{83} \mathrm{Jesi},{ }^{84}$ Moscosi di Cingoli ${ }^{85}$ and Cisterna di Tolentino. ${ }^{86}$ Recent archaeometric analyses conducted on the Mycenaean-type ceramics from these sites have attested that they were locally produced. The Mycenaean fragment from Treazzano di Monsampolo is the only sample that does not belong to the same cluster as the others. Its high chromium content suggests that it was probably imported from the Peloponnese. ${ }^{87}$

Although the sherd was previously published as a fragment of a stirrup jar shoulder, ${ }^{88}$ the organization of the decoration, consisting in a floral motif (FM 18,119) delimited by one broad band below and a group consisting of three narrower bands and at least five lines above, suggests that it belongs to a small piriform jar (either FT 45 or FT 48). ${ }^{89}$ Indeed, if the sherd belonged to a stirrup jar, there would not be any parallel bands and lines above the flower, but only a single band at the base of the false spout. ${ }^{90}$

However, the combination of motif and piriform jar is unusual. This kind of unvoluted flower is attested on stirrup jars, for instance at the House of the Oil Merchant at Mycenae (LH IIIB1), the Tiryns Epichosis (dated to LH IIIB Final/IIIC Early 1) ${ }^{91}$ in the Argolid, ${ }^{92}$ at Tsoungiza (LH IIIB1) in Corinthia, ${ }^{93}$ and, finally, at Pefkes (LH IIIB). ${ }^{94}$ The piriform jars FT 45 and FT 48 appear in LH IIIA2/IIIB1 and LH IIIB/IIIC Early 1 respectively. ${ }^{95}$

83 Vagnetti et al. 2006, 1168. - Sabbatini, Silvestrini, Milazzo $2009,245$.

84 VAGNETTi et al. 2006, 1168.

85 Sabbatini, Silvestrini, Milazzo 2009, 241.

86 Percossi, Pignocchi, Sabbatini 2005, 673.

87 Jones et al. 2014, 209-211.

88 Jones et al. 2014, 209.

89 Furumark 1941, (FT 45 or FT 48) 591-592, (FM 18,119) 293.

90 As the drawing does not provide any diameter, no statements can be made about the neck of the vessel.

91 Voigtlander 2003, 102 and Fig. 31/14, Pl. 73/14. - For the chronology of the Epichosis see KARDAMAKI 2015, 93-94.

92 Mountjoy 1999, 140 and Fig. 33/248.

93 Pit 1 , containing domestic refuse with no later contamination or apparent disturbance: Thомаs 2005, 453, 473 and Fig. 8/2.

94 Chamber tomb 3, on top of pit II: ViKatou 2001, 104, 105 and Fig. 45 (however with double outline).

95 Piriform jars FT 45 are attested, for instance, at the Petsas House at Mycenae dated to LH IIIA2 (Shelton 2007, 173 and Pl. XLVI) and at Pefkes dated to the LH IIIB (Vikatou 2001, 99, 105 and Fig. 46); piriform jars FT 48 are known from Tiryns, dated to the LH IIIB (Voigtlander 2003, 114 and Pl. 143) and from the House of the Sphinxes at Mycenae dated to LH IIIB1 (FrenCH 1967, 154 and Figs. 4-5).
Since the Mycenaean sherd from Treazzano di Monsampolo was not found during the excavation but is part of a collection due to a previous survey conducted by amateurs, its provenance is often discussed. However, both the shape and decoration of the fragment could be dated to a period between the end of LH IIIA2 and LH IIIB coeval to the RBA, which is the main chronological horizon of the impasto pottery found at the site.

\section{Conclusions}

The study of the archaeological finds at Treazzano di Monsampolo leads us to state the existence of a settlement dated to a period between the end of the MBA and the late phase of the RBA (or probably the very beginning of the FBA). The first occupation of the site could, most likely, be dated to MBA 3, as attested by the presence of a few fragments with Apennine decorations and some vessels which have parallels in shapes diffused at the end of the MBA period. Except for these materials, the pottery found at Treazzano di Monsampolo belongs to the Subapennine facies and clearly shows that the settlement was in use during the whole RBA period. The abandonment of the settlement can be dated to the end of RBA 2 or the beginning of the FBA. A few pieces from Treazzano di Monsampolo are comparable with FBA specimens but they could also belong to the last stage of RBA 2 . This abandonment seems to correlate with a more general phenomenon that occurred at the transition between the RBA and FBA. In this period, especially in central Italy, people started to move from open sites to more defendable zones.

Even if the Subapennine facies can still be considered 'the earliest Italian cultural unit' (as Peroni defined it), ${ }^{96}$ some typical characteristics of the pottery at Treazzano di Monsampolo have been exclusively recognized in the central and southern Adriatic regions, such as the prevalence of bird-shaped knobs instead of horns and the lack or the scarce number of the straight-cylinder knobs. These latter have long been classified as fossil types of RBA 1. Based on their absence, ${ }^{97}$ Treazzano di Monsampolo was dated to RBA 2 by previous studies. ${ }^{98}$ However, Treazzano di Monsapolo does not represent an isolated case: the frequency of the straight-cylinder knob is very low in the area between the South Marche and the lower Adriatic area. ${ }^{99}$ The similarities which characterize the pottery of the Adriatic

96 PERONi 1989, 352-354.

97 CATTANi 2009, 252 reported the presence of two fragments of straight-cylinder knobs from the site, but the author did not find any evidence within the material stored in the Museum of Ascoli Piceno. 98 Lollini 1982. - Lucentini 1995.

99 CATTANi 2009. 
macro-region suggest possible contacts, probably passing through the Tronto Plain (Tab. 2).

The chronotypological analysis of the archaeological materials presented in this paper also allows us to identify parallels with the Terramare area. Research conducted in the Po Plain and central Adriatic regions has shown a cultural osmosis between the two areas documented, besides the antler industry, by strong parallels in metallurgic and pottery production. Although the majority of the Subapennine settlements where Terramare influences are more evident are located in the northern part of the region (i.e. Moscosi di Cingoli, Cortine di Fabriano, Conelle di Arcevia, and Cisterna di Tolentino), some characteristics of the Terramare traditions have also been identified in the southernmost sites of the Marche region.

First of all, it is possible to identify Terramare influences in antler artefacts found at Treazzano di Monsampolo and Laferola di Acquaviva Picena; secondly, in elements characterizing the pottery collected in some of the settlements of the Tronto Plain - as well as at Treazzano di Monsampolo, at Colli del Tronto and Offida. Among the pottery of Treazzano di Monsampolo, few pieces have decorations with grooves, which are typical elements of the Terramare facies. At the site, this decoration occurs on some handles (mainly with a circular section), on three non-joining wall fragments, on the rim of a shallow bowl and on the beak and the body of a beak-handled jar. The handles with hornshaped knobs decorated with grooves, largely attested in Terramare area and also widespread in the northern part of Marche region, ${ }^{100}$ are represented by only two fragmentary specimens at Treazzano di Monsampolo. In both cases, the knobs are not preserved, but it is possible to note a decoration composed of grooves on the trunk and on the connection of the knobs where one of the specimens presents a small central boss (Pl. 6/C1), which also occurs in other specimens both from Terramare and the northern Adriatic area. Besides the two specimens from Treazzano di Monsampolo, two other similar handles have been recognized in the southern Marche territory, one from Offida and the other one from Colli del Tronto. ${ }^{101}$

At Treazzano di Monsampolo an interesting wall fragment has also been found (Pl. 1/C1), decorated with transversal, horizontal and wavy grooves, probably related to a biconical jar. ${ }^{102}$ Such a sherd has a very close parallel in a specimen coming from Fiobbo (Colli del Tronto, southern

100 Evidence has been found at Moscosi di Cingoli, Cisterna di Tolentino, Frasassi Cave, S. Paolina di Filottrano and Gola del Sentino. 101 Lucentini 1987, 437-494.

102 Damiani 2010, 455.
Marche) and might be a local re-interpretation of a decorative motif largely attested on jars at Moscosi di Cingoli, where the grooves have a more regular disposition. ${ }^{103}$ In turn, such decoration appears in several sites of the Po Plain area ${ }^{104}$ and, although it is sporadically present in central and southern Italy, ${ }^{105}$ it is considered as belonging to the Terramare tradition. Likewise, the grooves decorating the beak and the body of one of the two beak-handled jars (P1. 9/B2) found at Treazzano di Monampolo seem to derive from the same tradition. In this case, the decoration clearly has Terramare influences but the shape is characteristic of the Subapennine facies. Indeed the type is mainly attested in central and southern Italy ${ }^{106}$ while it is less represented in the northern regions. ${ }^{107}$ Another element connecting the pottery of Treazzano di Monsampolo and that coming from the Terramare area is constituted by the small zoomorphic clay figurines. The three figurines of Treazzano di Monsampolo, which probably represent horses, have comparisons with similar objects mainly found in Emilia Romagna and the Po Plain. ${ }^{108}$

To summarize, the co-presence of 'northern' (not numerous) and 'southern' elements characterizing Treazzano di Monsampolo pottery suggests the existence of contacts with both the areas and supports the hypothesis, already assumed by previous studies, of the existence of a link between the two areas passing through the Marche region. The findings of Mycenaean-like pottery at Montagnolo di Ancona, Jesi, Moscosi di Cingoli and Cisterna di Tolentino, ${ }^{109}$ together with the discovery of the Mycenaean pottery fragment at Treazzano di Monsampolo, seem to provide evidence of the cultural and economic importance of the region, which was a 'hinge' area connecting the northern part of the Peninsula and the south, directly involved in the Aegean traffic. ${ }^{110}$ Unfortunately, the lack of systematic excavations, in particular in the southern area of the region, and the limited data at our disposal do not allow for a thorough investigation into the mediation role played by the region.

103 Cf. Sabbatini, Silvestrini 2005, Fig. 3/1-4.

104 Cf. Bianchi 2004, Fig. 10/3. - Cardarelli, Pellacani 2004, Fig. 4/8.

105 For central Italy cf. MANDOLESI 1993, Fig. 3/A5. - For southern Italy cf. Arancio et al. 2001, Fig. 46/1.

106 For central Italy cf. Damiani 2010, Pl. 84/5. - Pignocchi, Silvestrini 2015, Fig. 2/7. - For southern Italy cf. Cataldo 1995, Pl. 40/1. - Lo PORTo 1997, Fig. 67/1.

107 Caironi, Guerra, Vaccari 2009, 236-237.

108 Bianchi 2004, Fig. 14/1-11. - Damiani 2010, Fig. 4/7.

109 Jones et al. 2014, 209-211.

110 Percossi, Pignocchi, Sabbatini 2005, 672-675. 


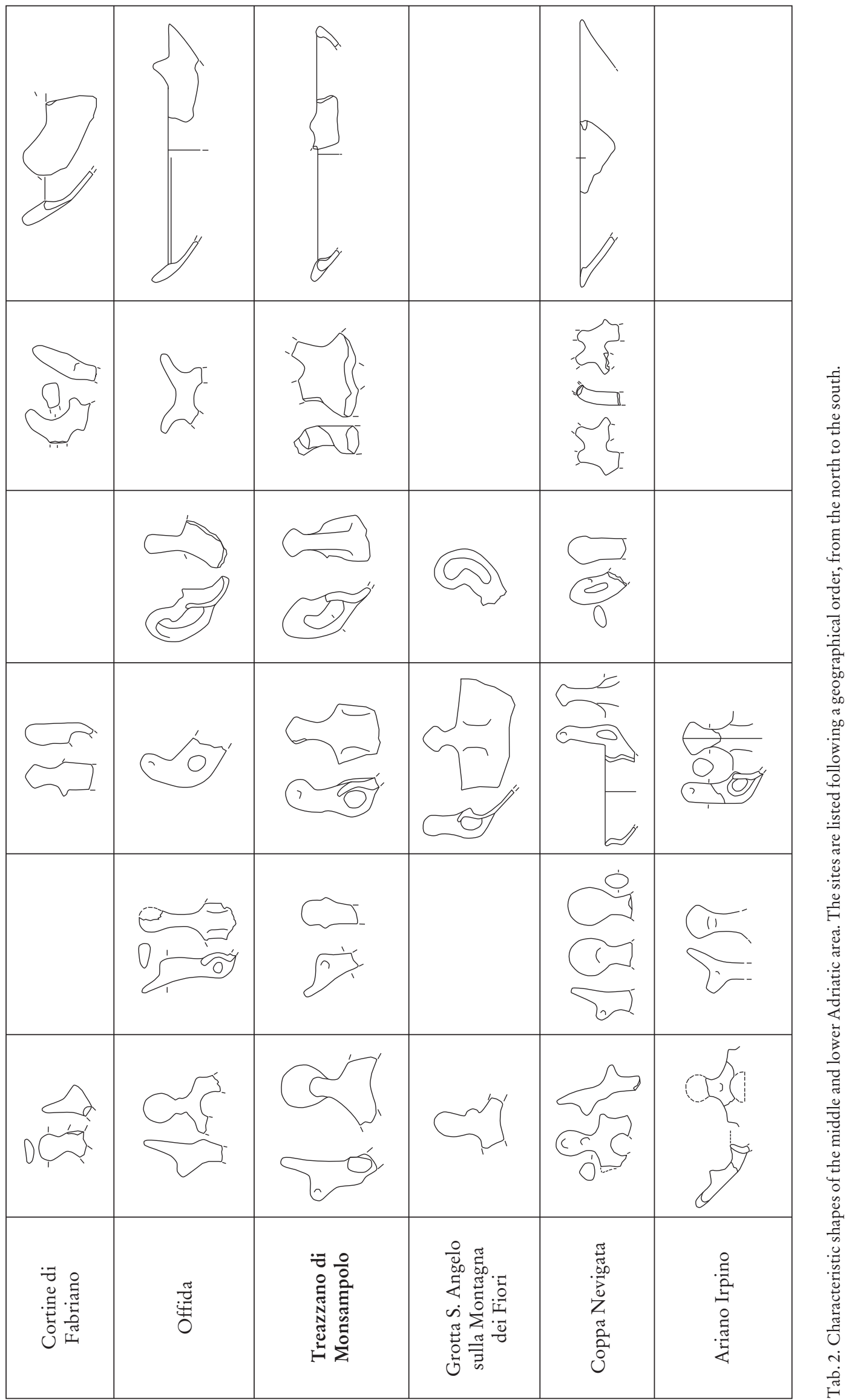



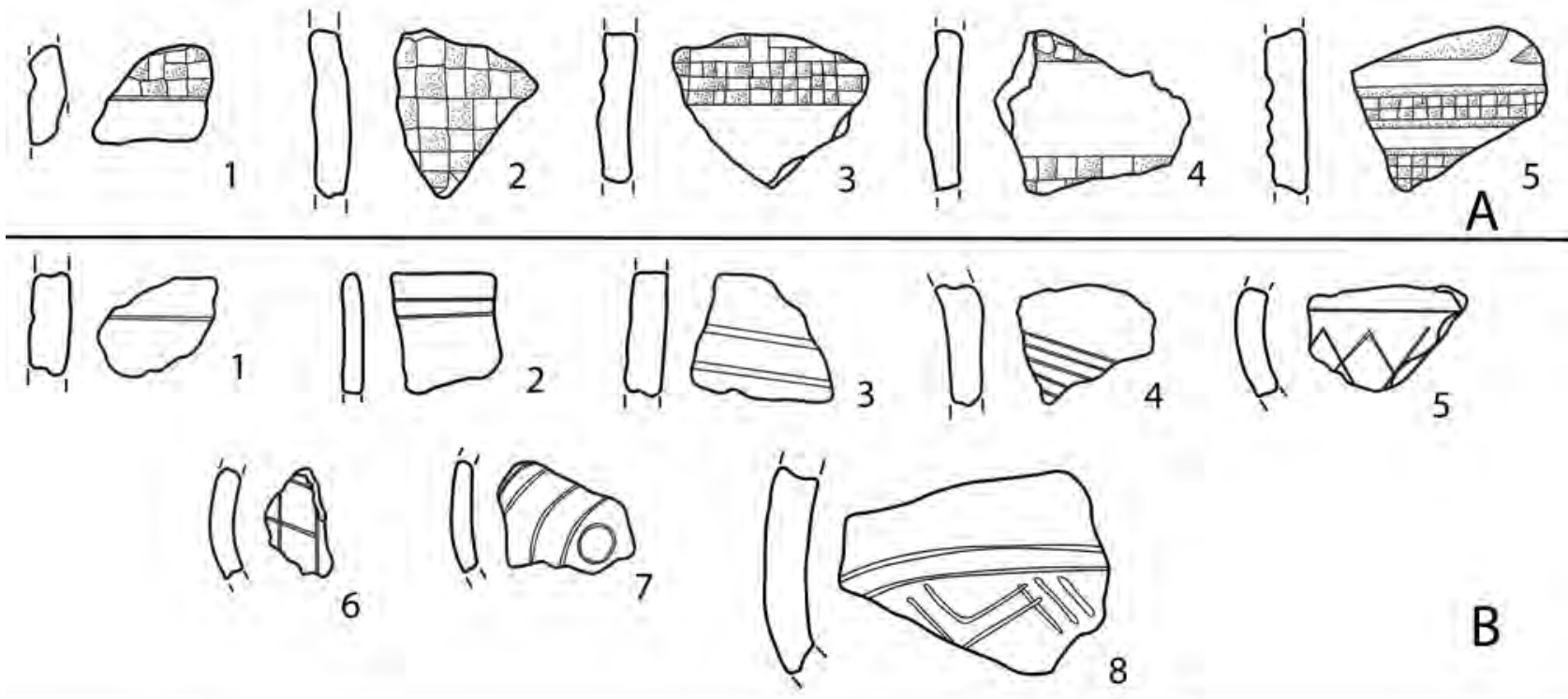

B
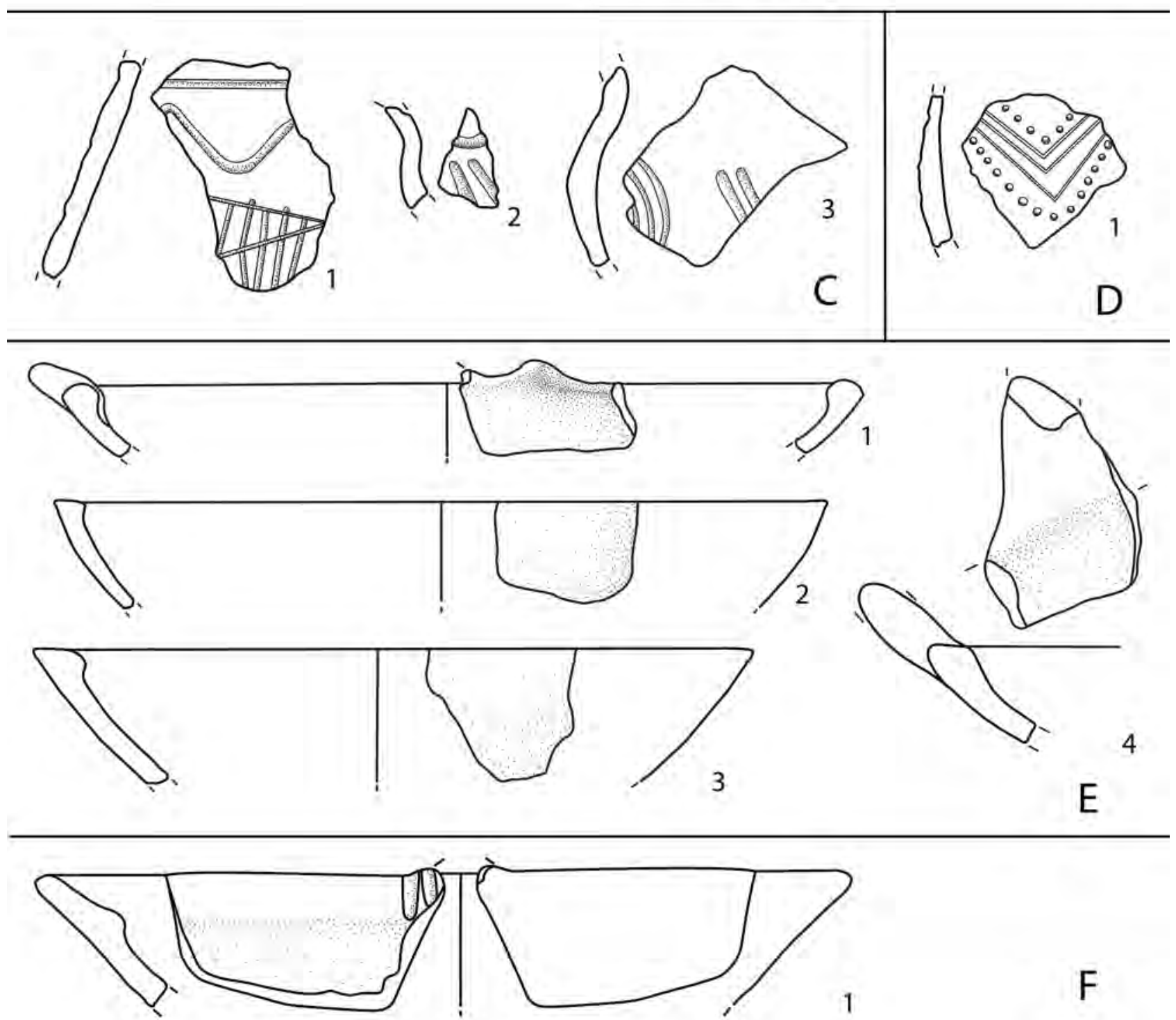

F

Pl. 1. Treazzano di Monsampolo, pottery. - A-D: Apennine pottery (1:2). - E-F: Bowls (1:2). 

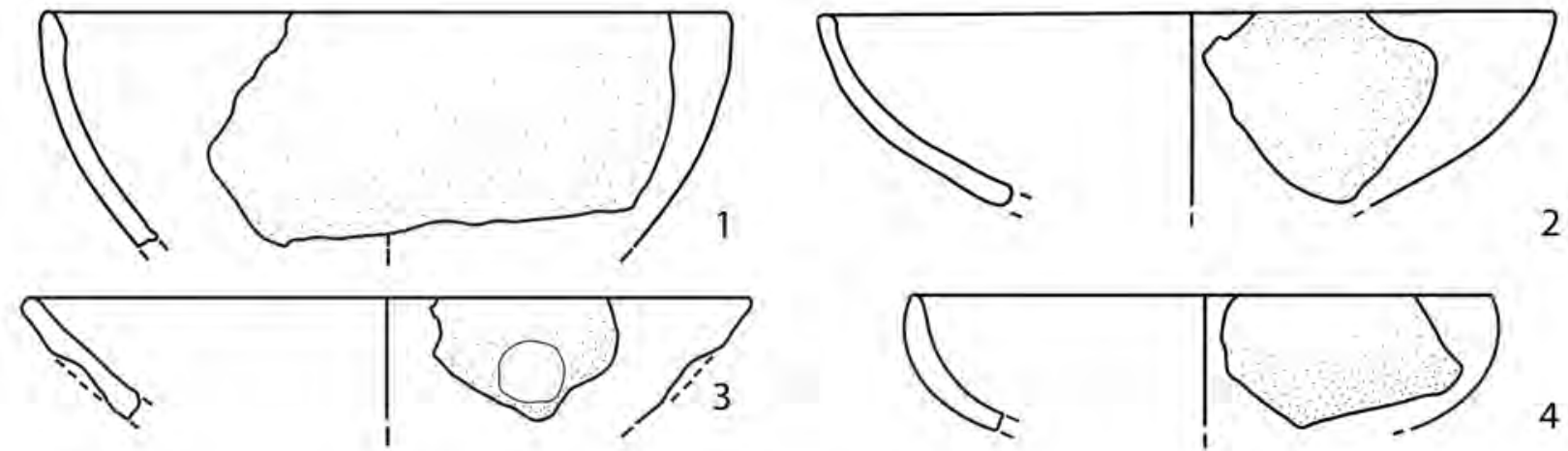

2
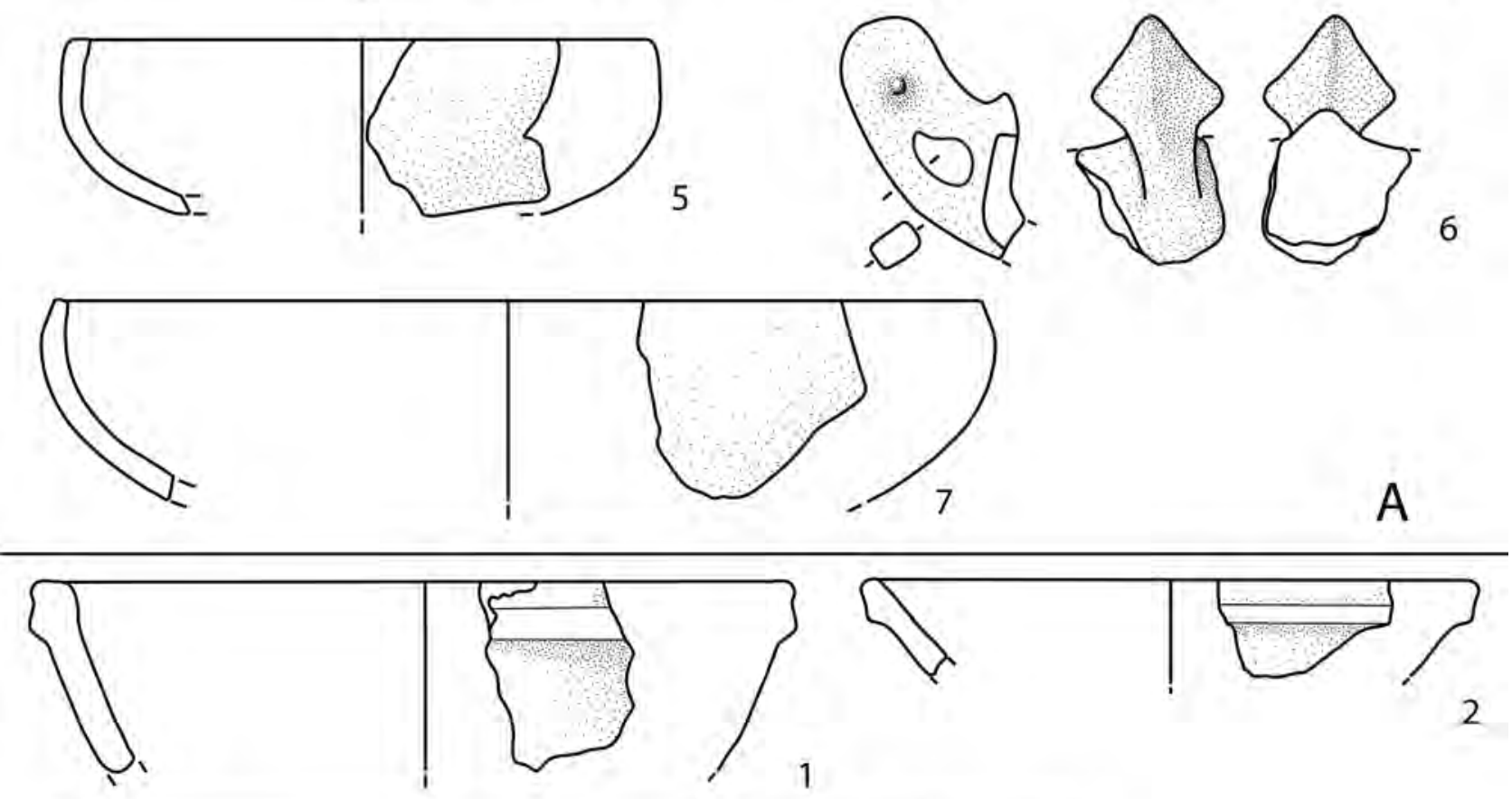

1
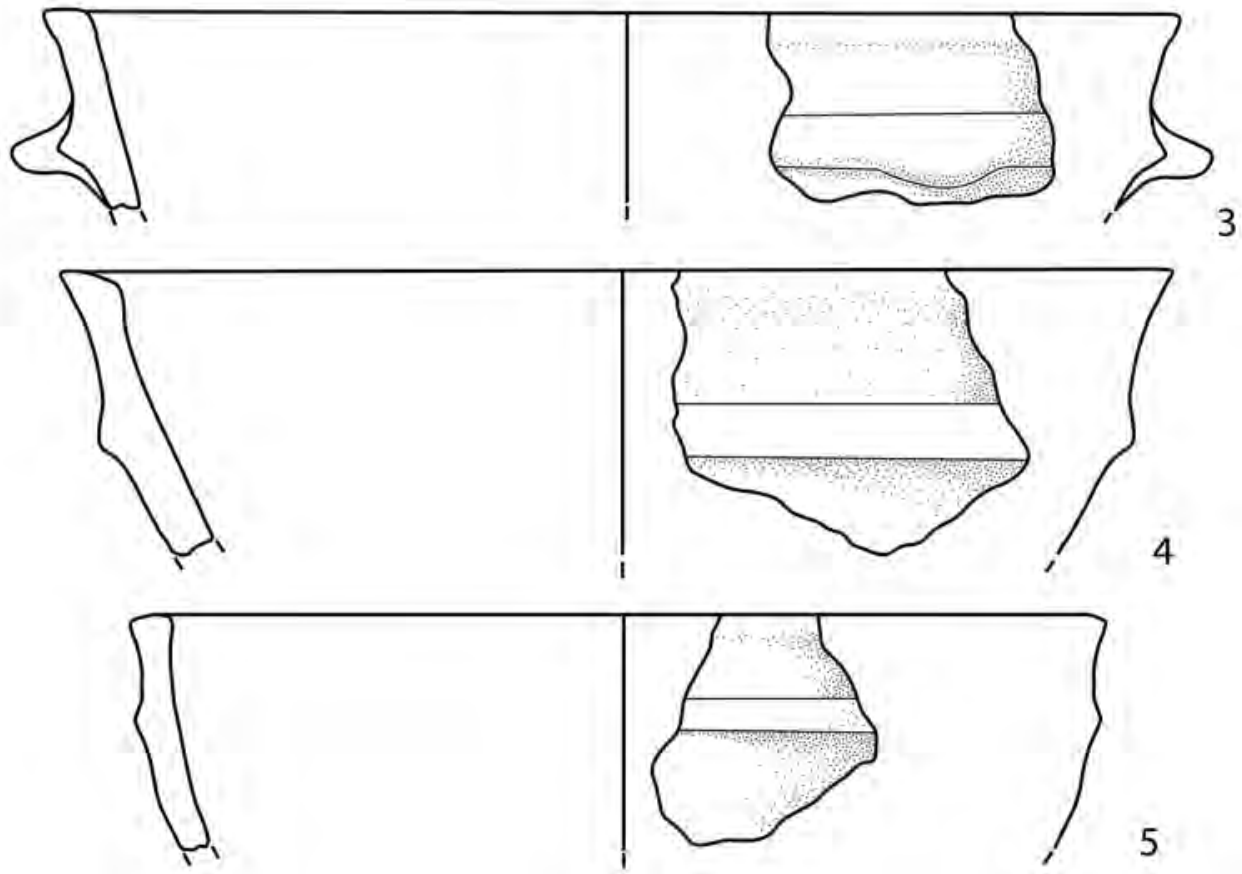

B

Pl. 2. Treazzano di Monsampolo, pottery. - A-B: Bowls (1:3). 

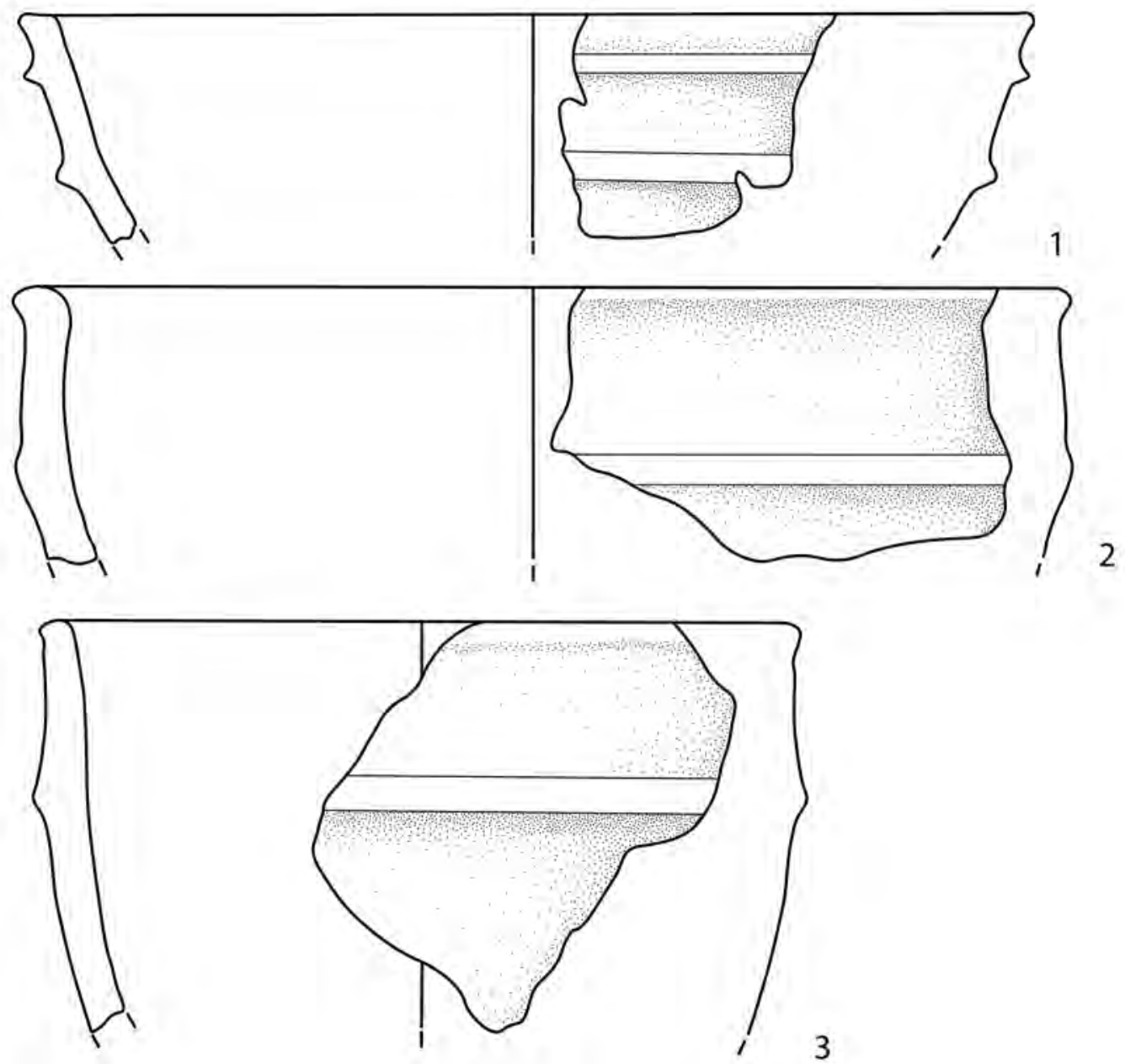

3
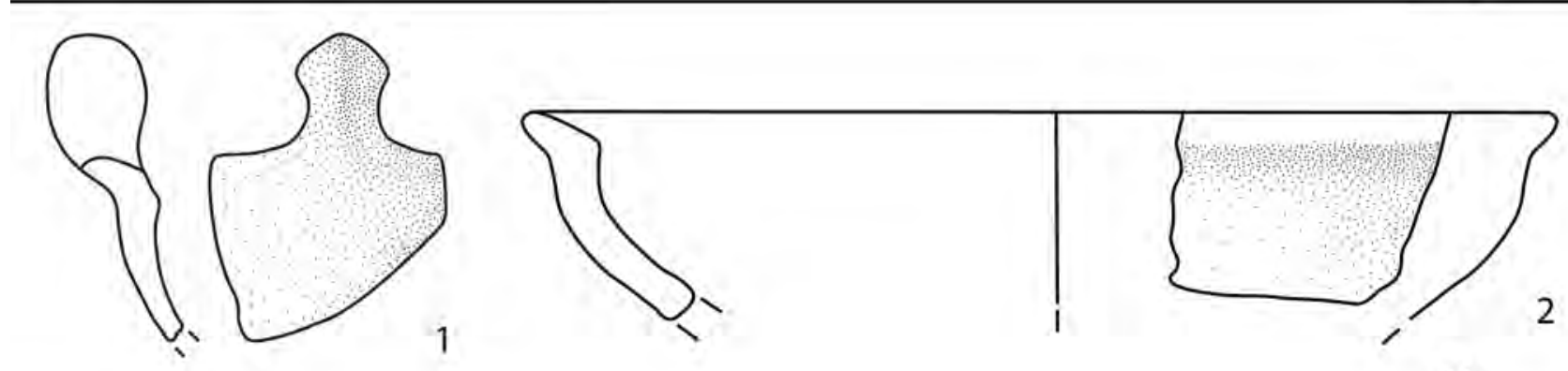

B

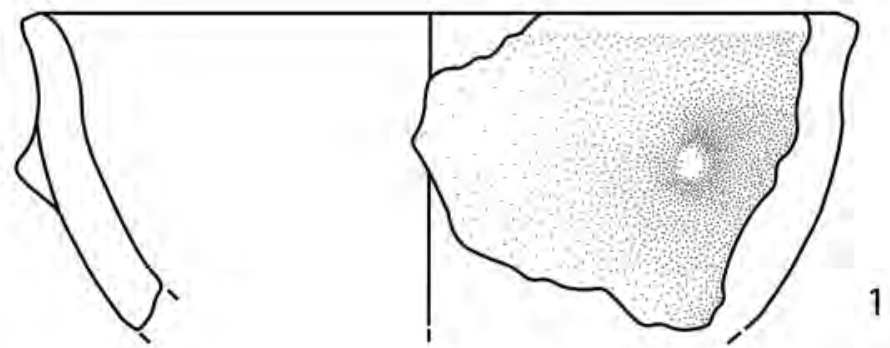

C

Pl. 3. Treazzano di Monsampolo, pottery. - A: Large Bowls (1:3). - B-C: Medium-sized bowls (1:2). 

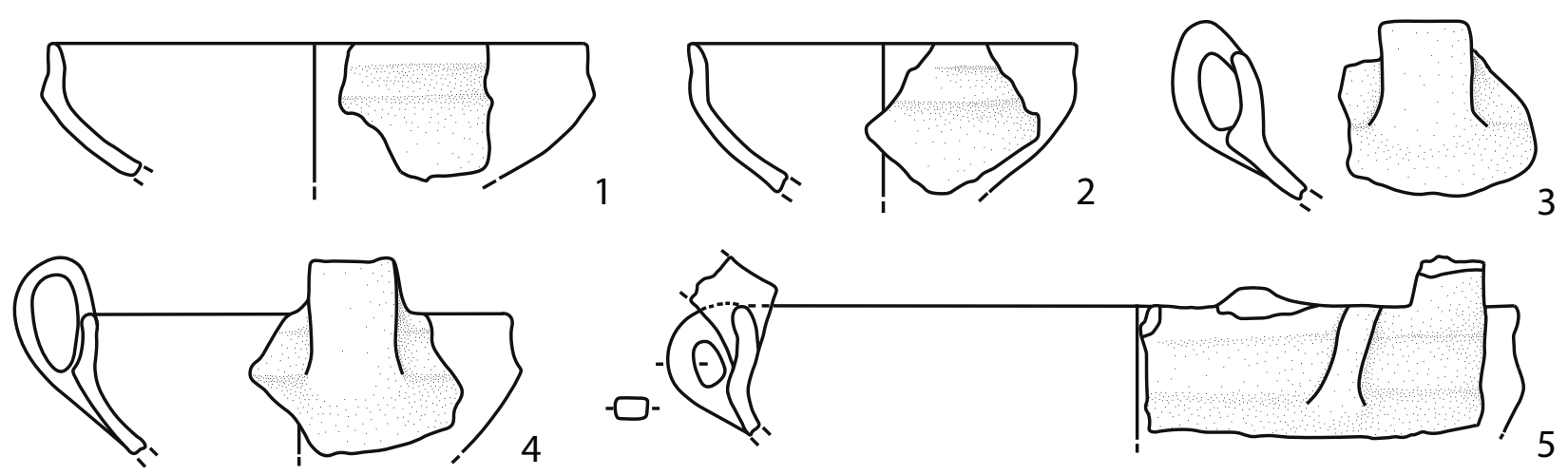

A
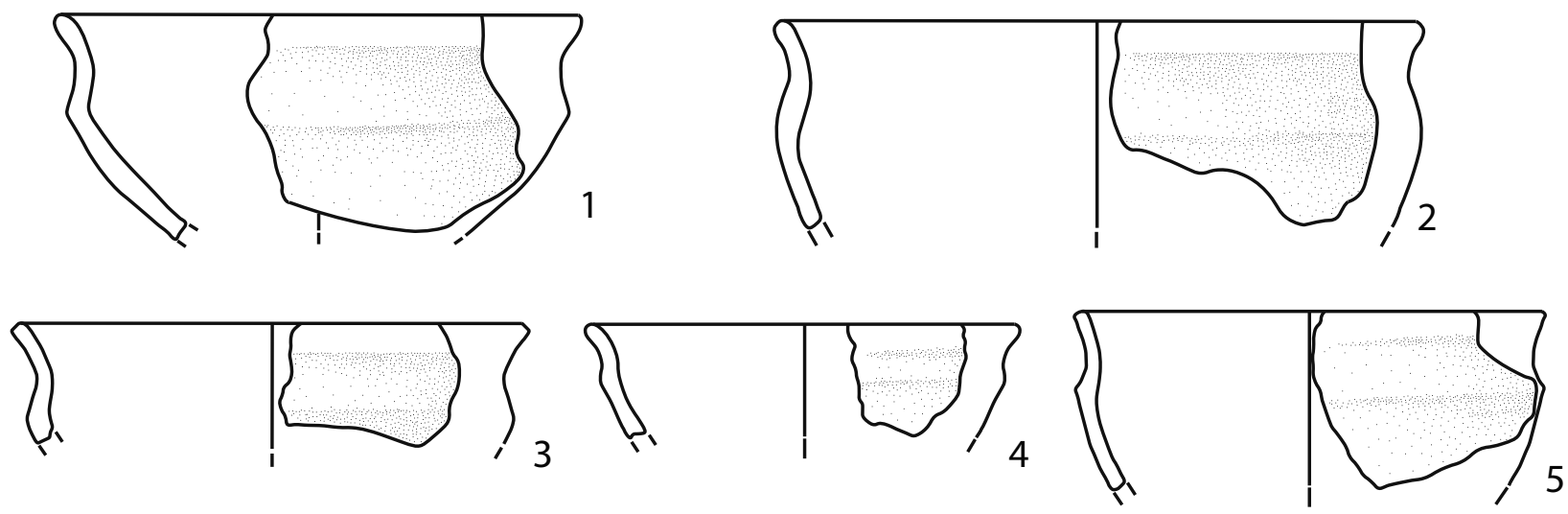

B
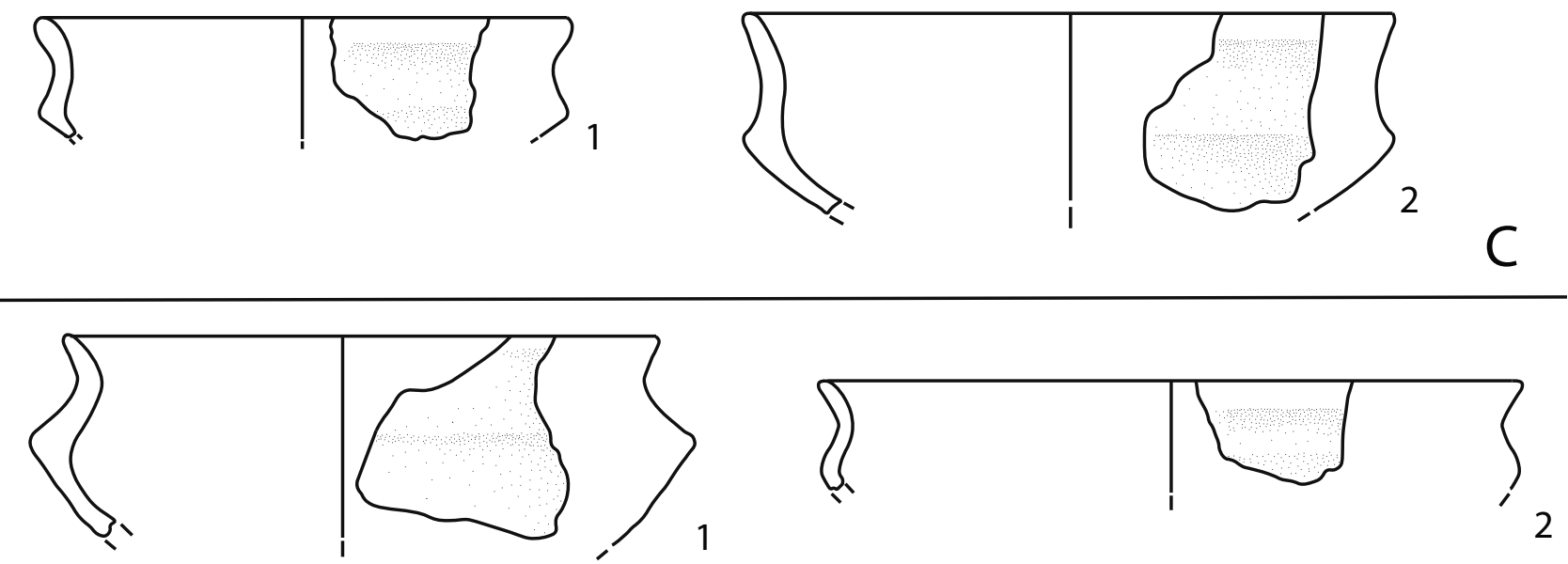

D

Pl. 4. Treazzano di Monsampolo, pottery. - A-D: Carinated cups (1:3). 

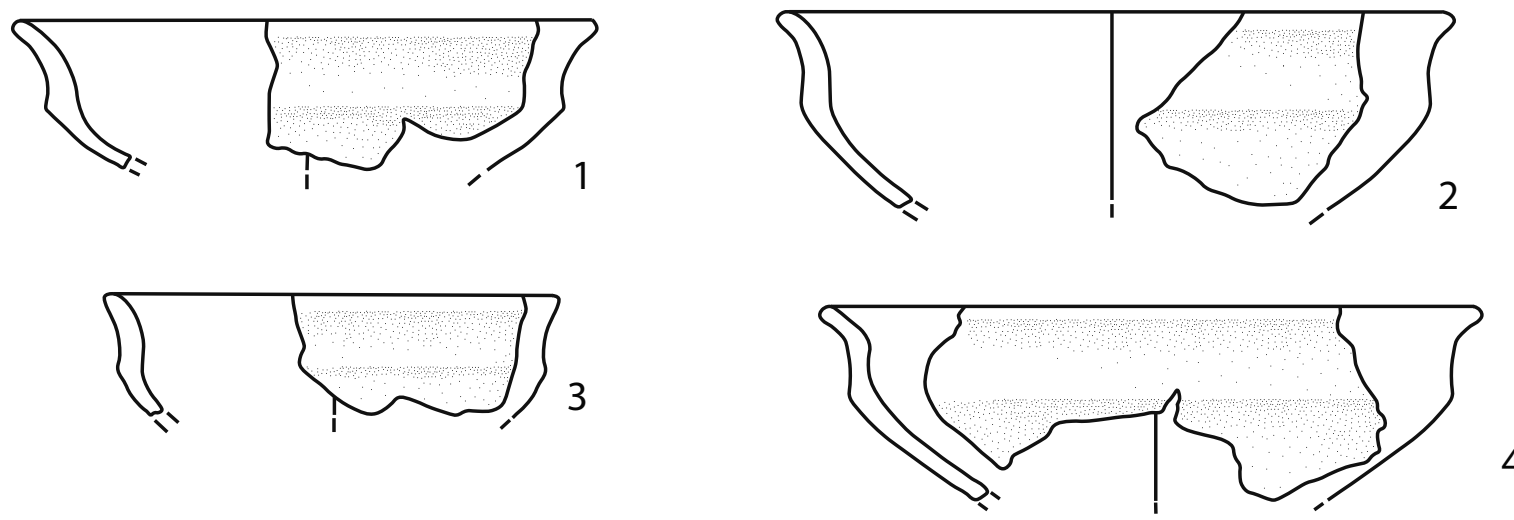

4

A
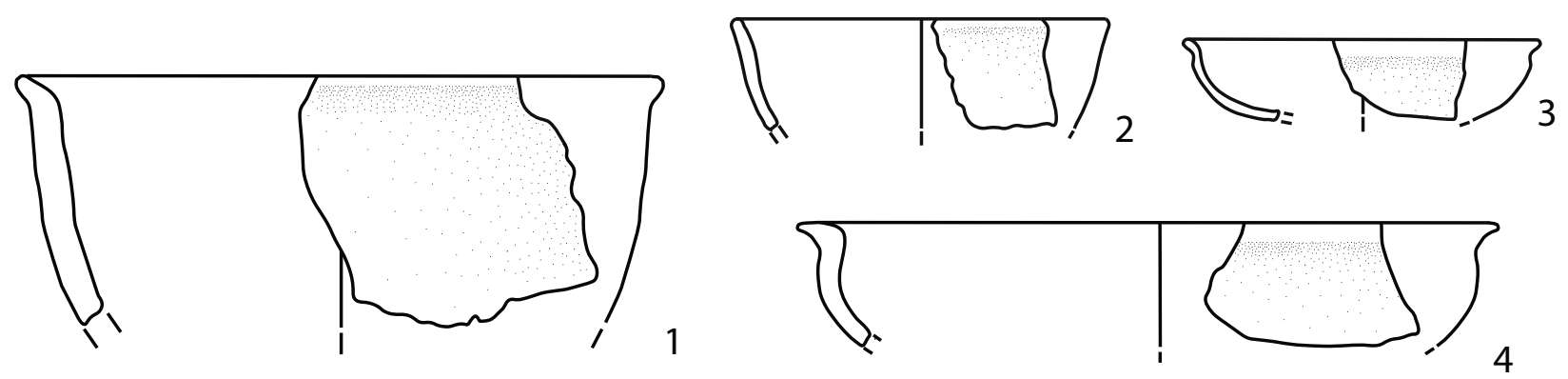

B
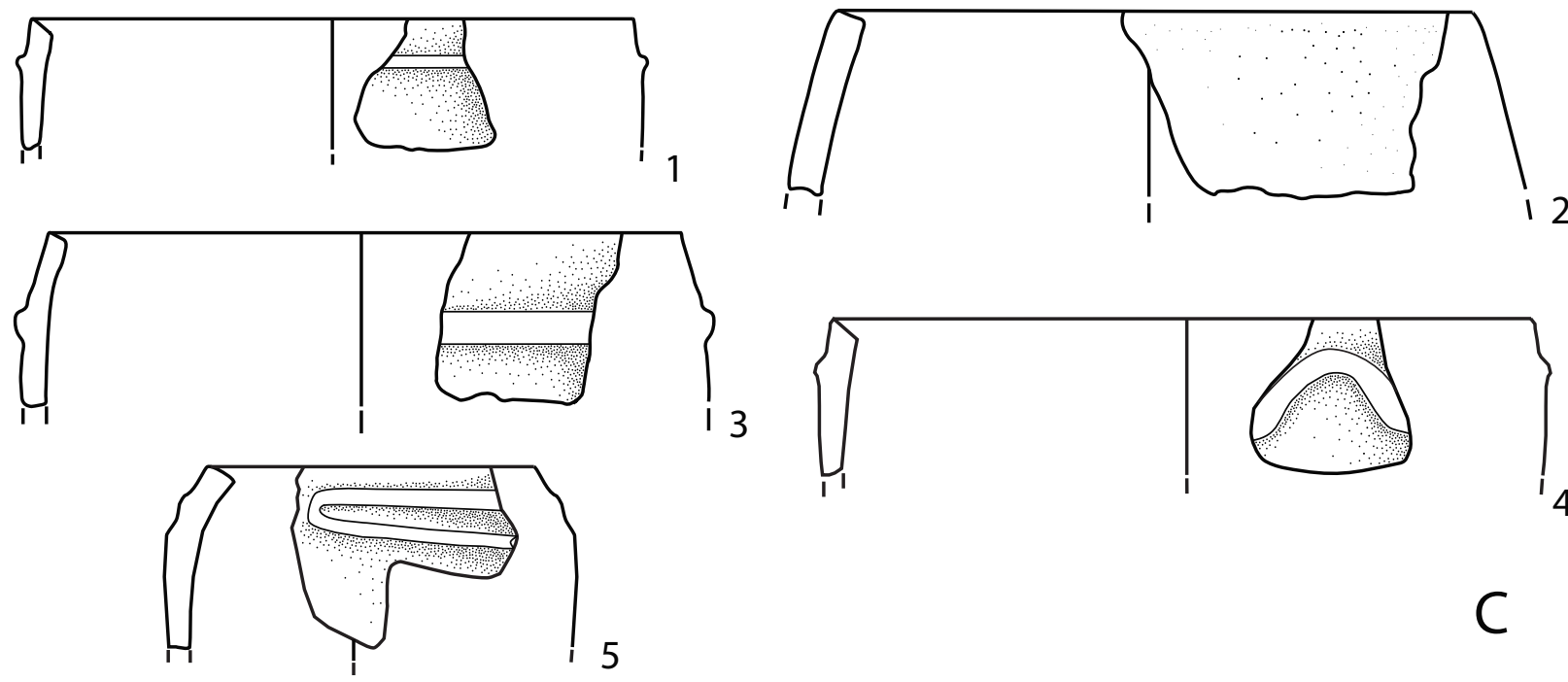

Pl. 5. Treazzano di Monsampolo, pottery. - A: Carinated cups (1:3). - B: Cups with a convex profile (1:3). - C: Cylindrical jars (1:3). 
$2 C_{1}^{2}$

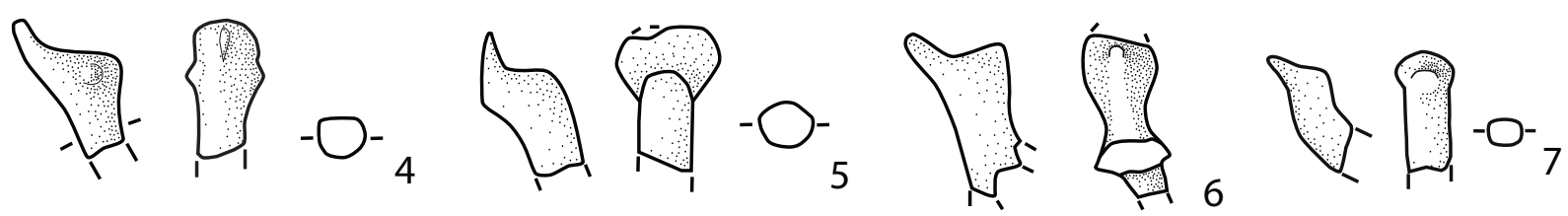<smiles>C1CCC2CCCC2CC1</smiles>
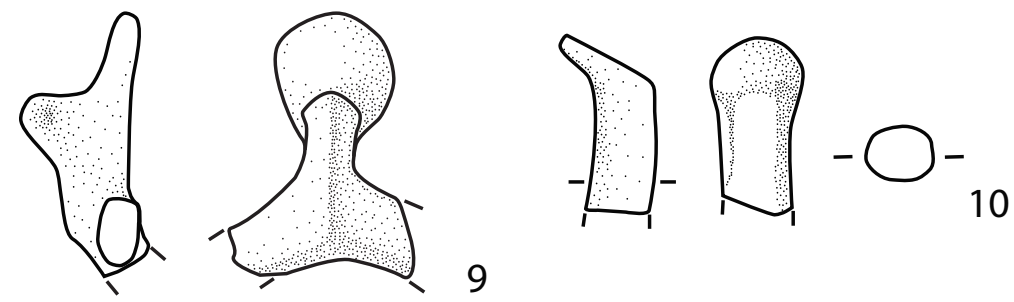

A
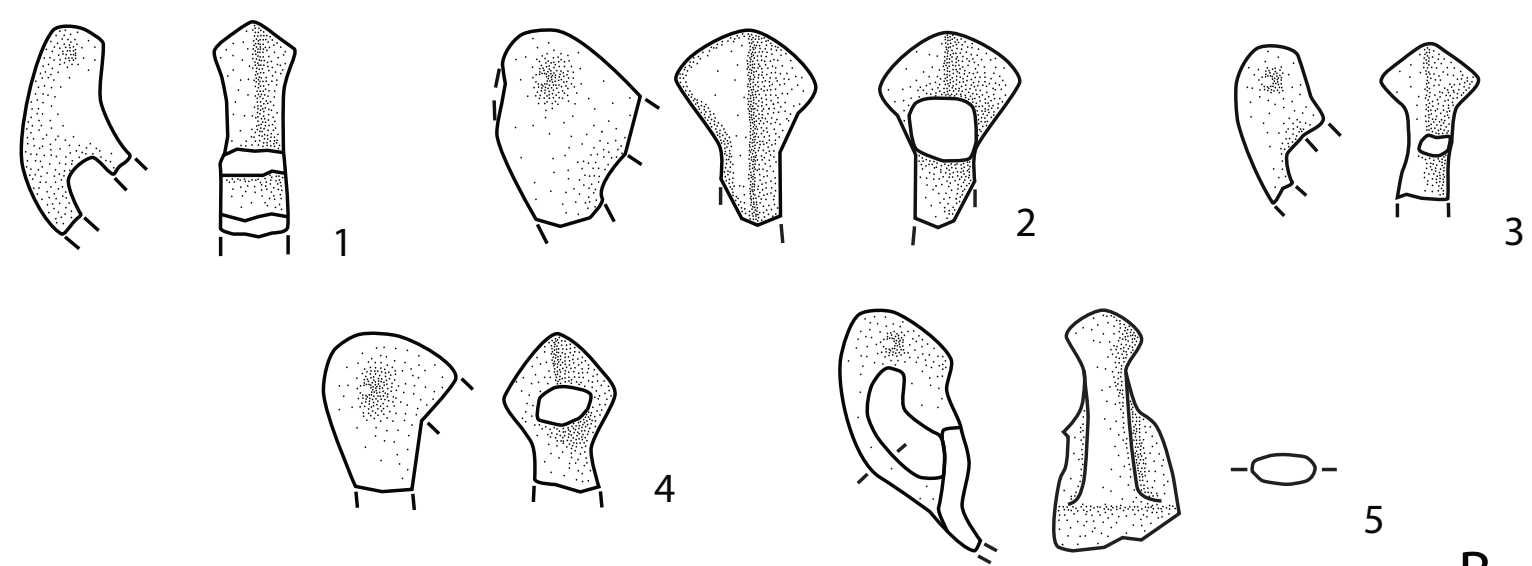

B

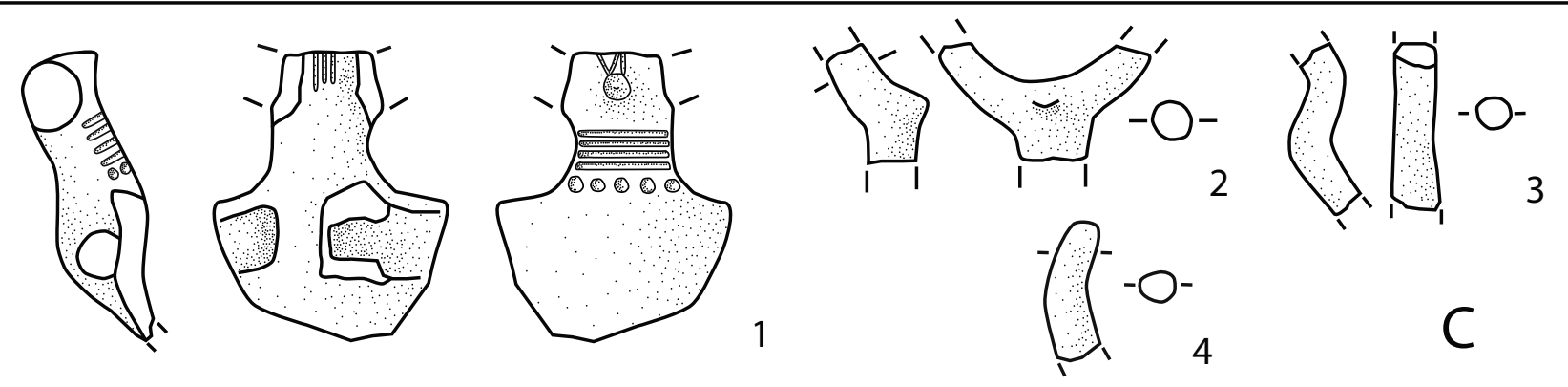

Pl. 6. Treazzano di Monsampolo, pottery. - A: Bird-shaped knobs with beak curved upwards (1:4; nos. 6-8: 1:3). - B: Bird-shaped knobs with beak turned towards the interior of the vessel (1:3). - C: Horn-shaped knobs (1:3). 

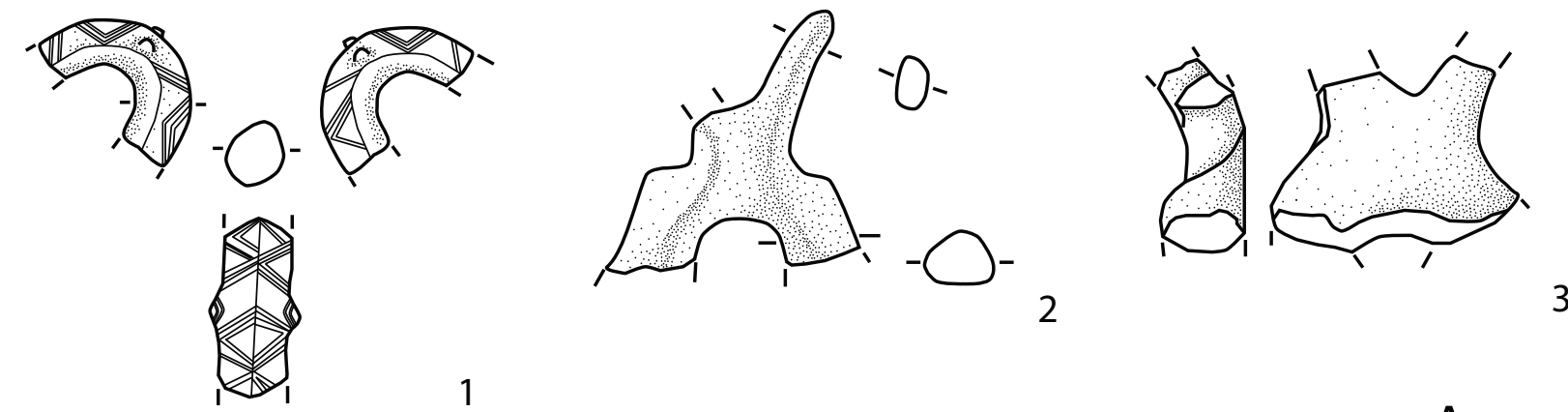

A

$=\int_{-1}$
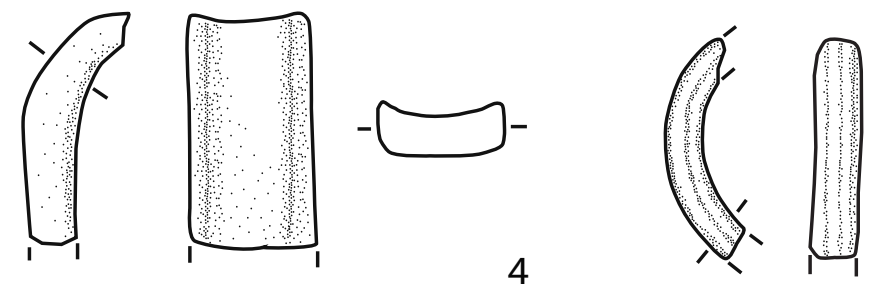

-
5

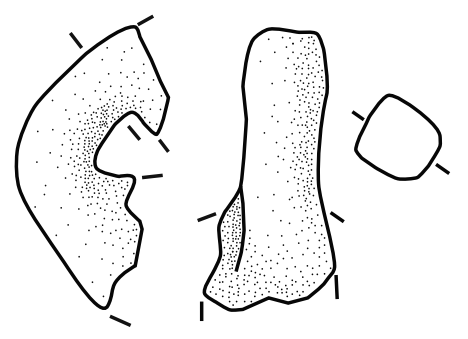

6
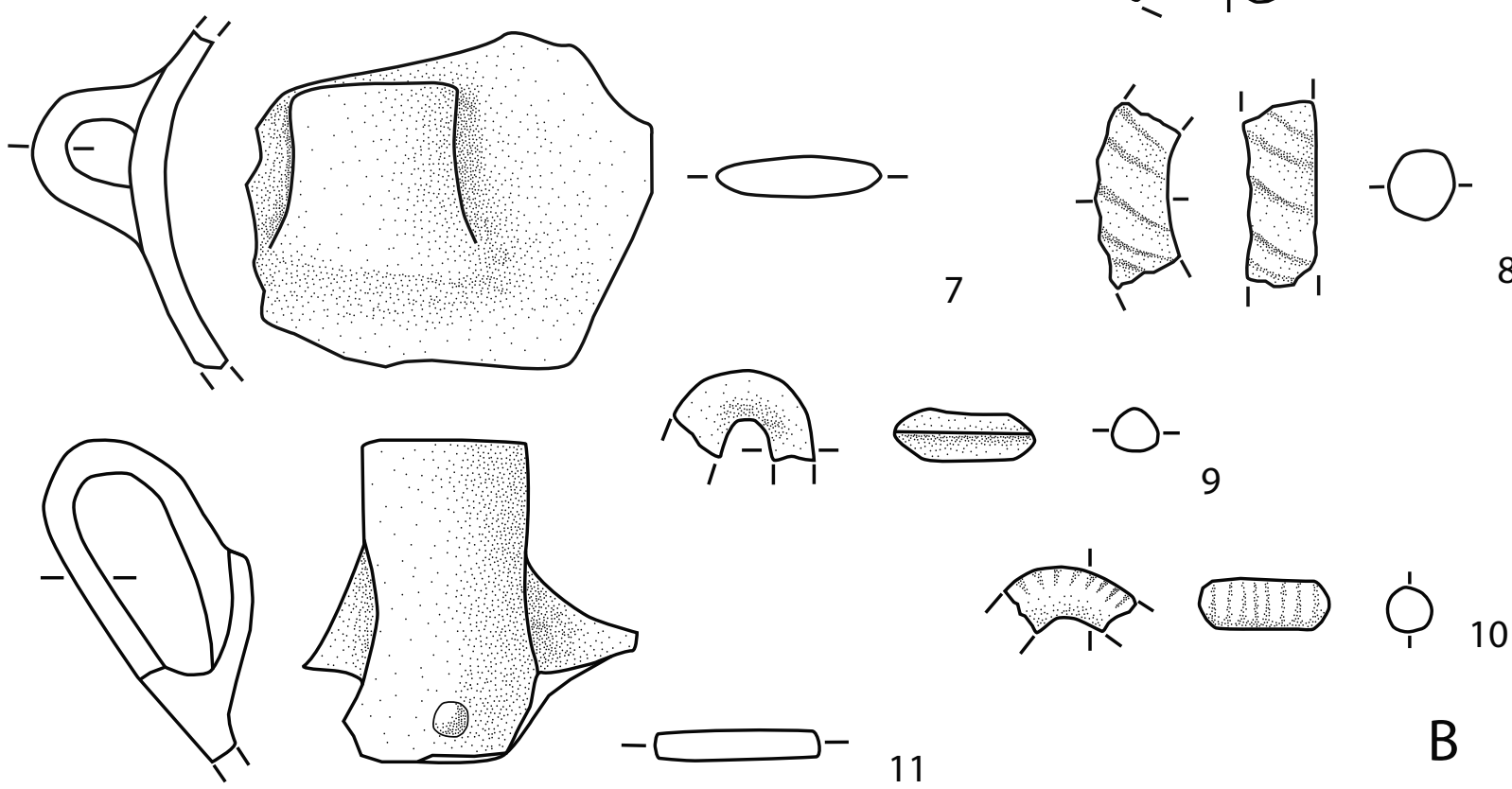

9

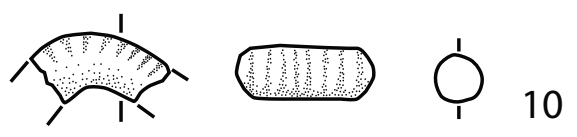

11

B

Pl. 7. Treazzano di Monsampolo, pottery. - A: Equine handle and handles with volutes (1:3). - B: Strap and tubular handles (1:3). 

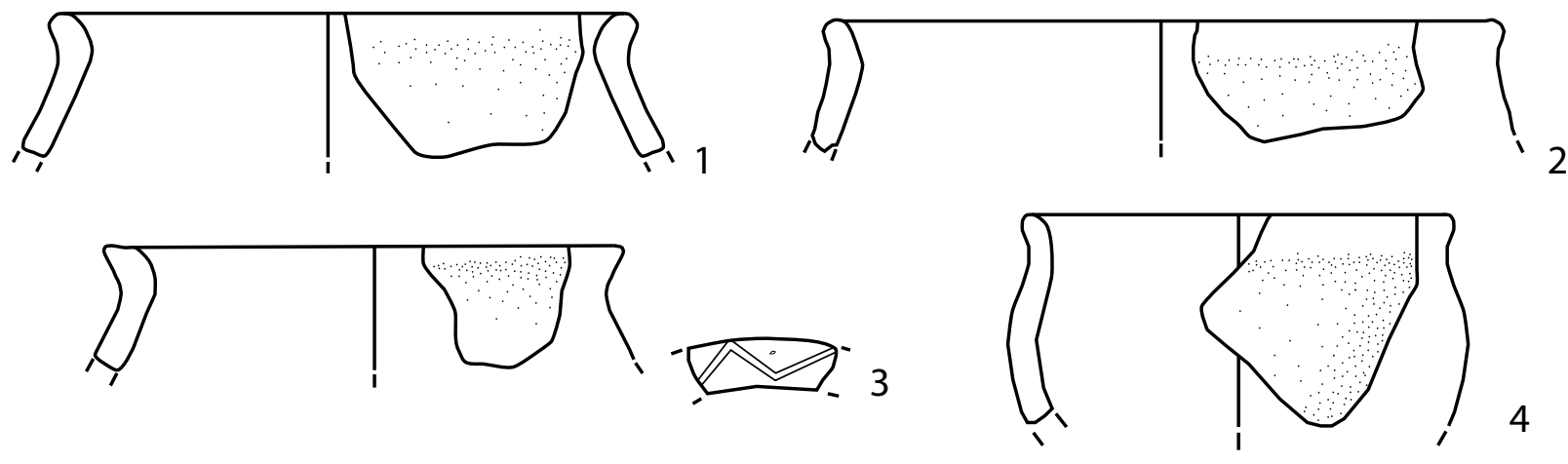

4
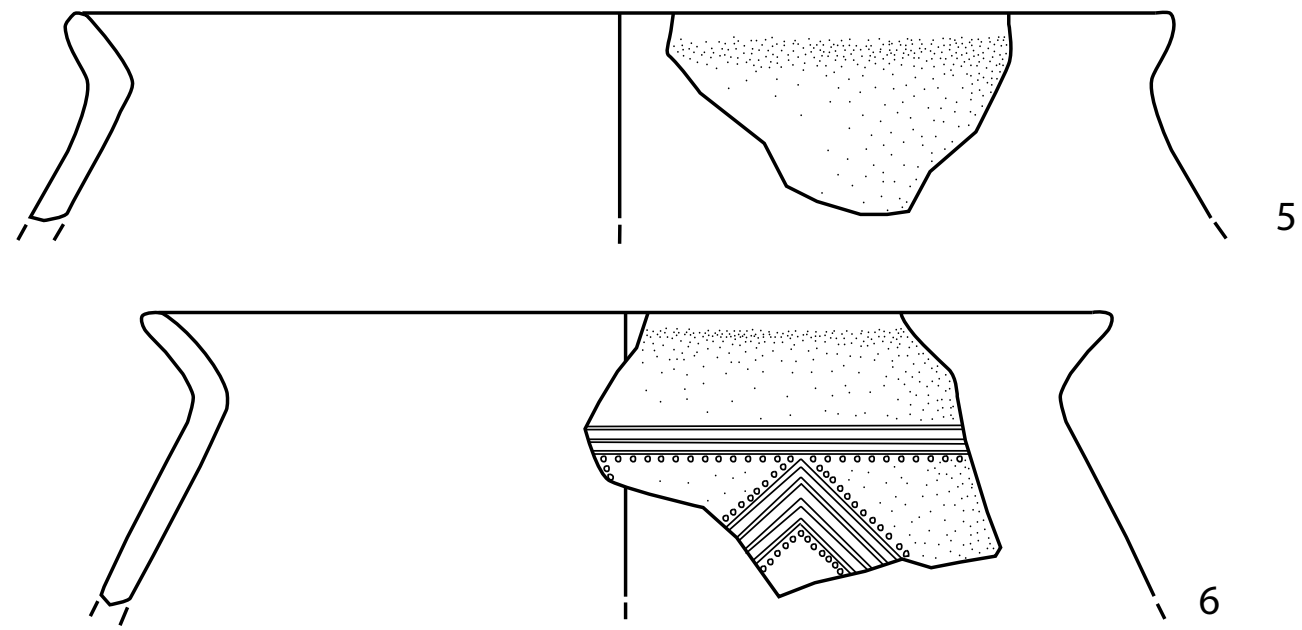

A

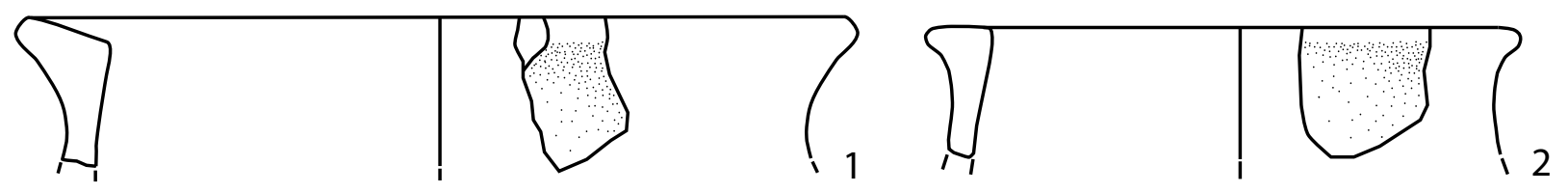

B
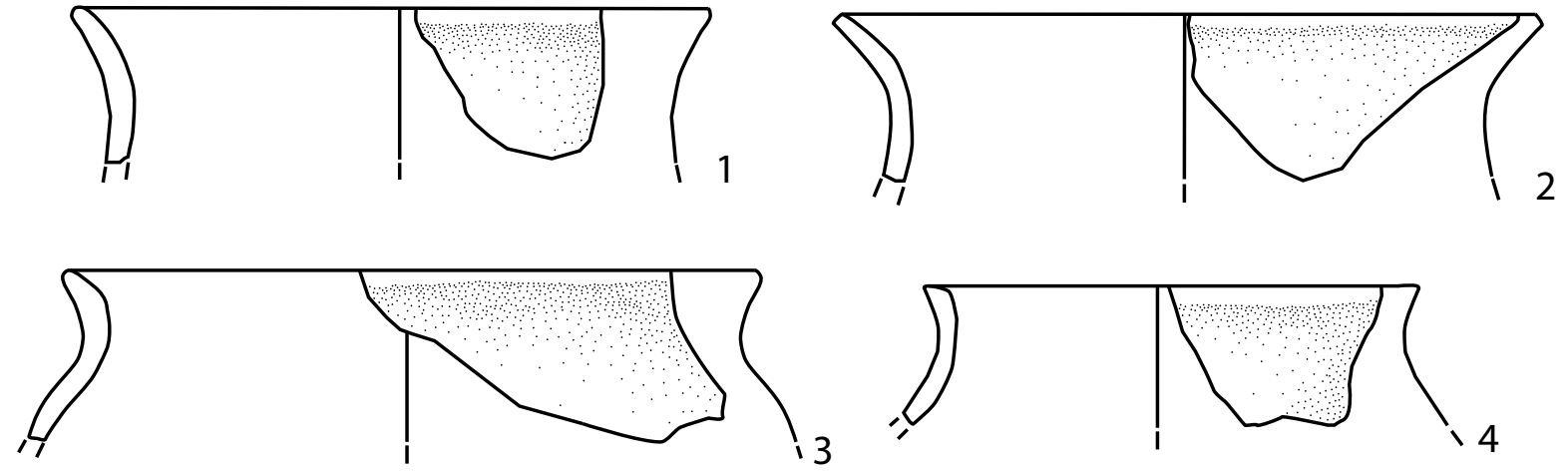

Pl. 8. Treazzano di Monsampolo, pottery. - A: Jars with an ovoid body (1:3; nos. 3 and 6:1:2). - B: Jars with a rim characterized by an internal edge (1:3). - C: Jars with a concave neck (1:4). 

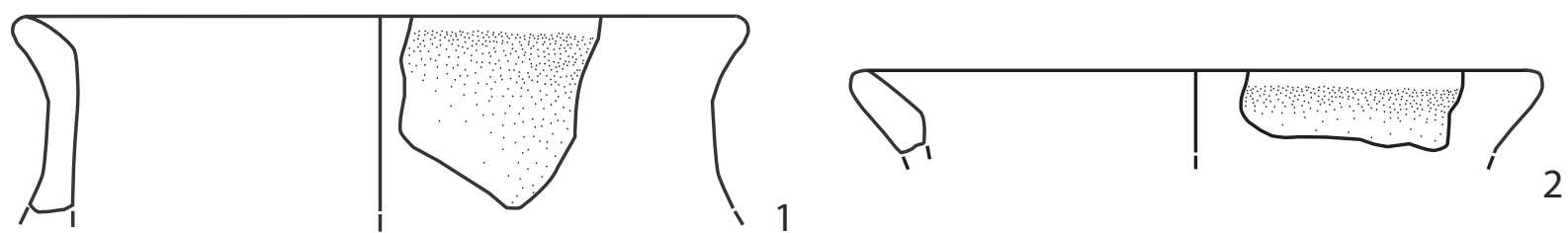

A
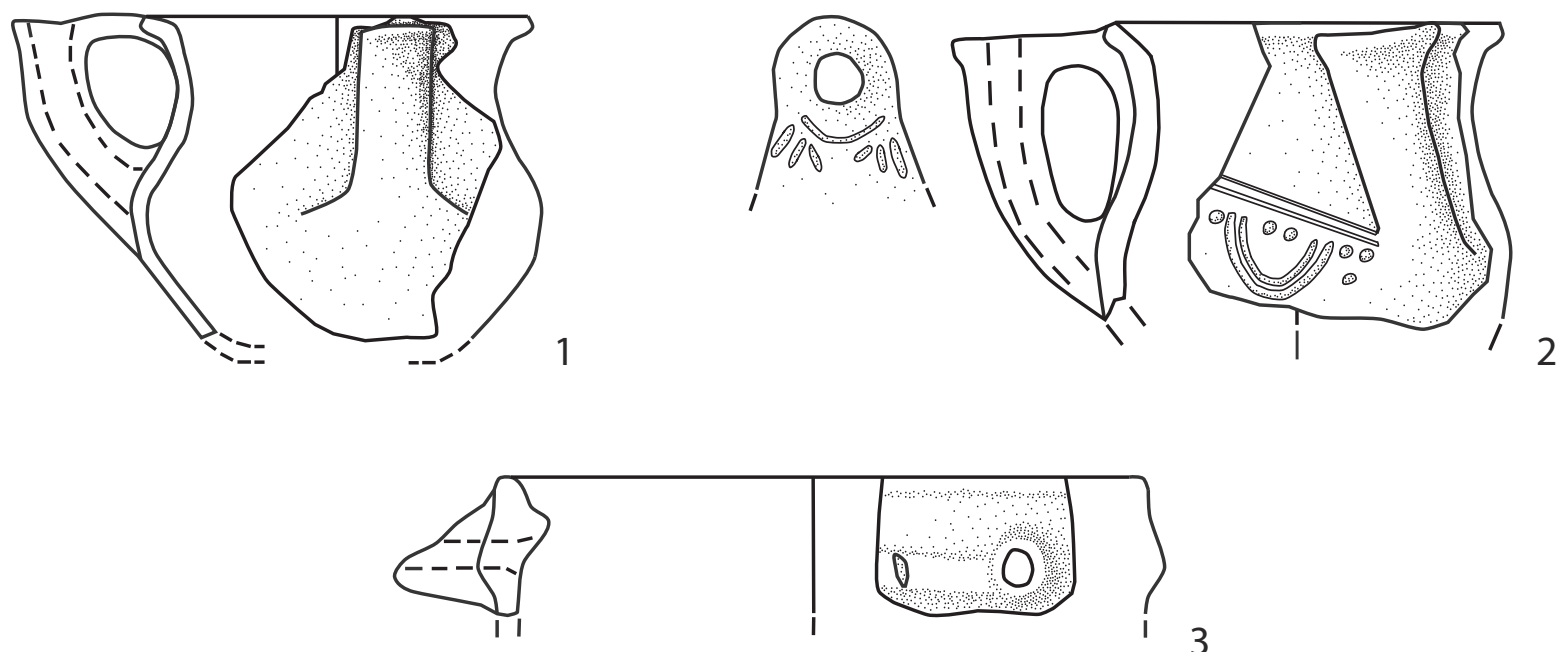

3

B
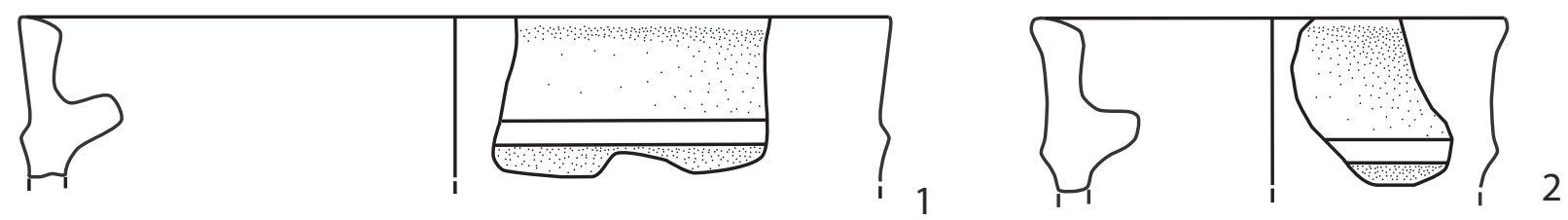

C

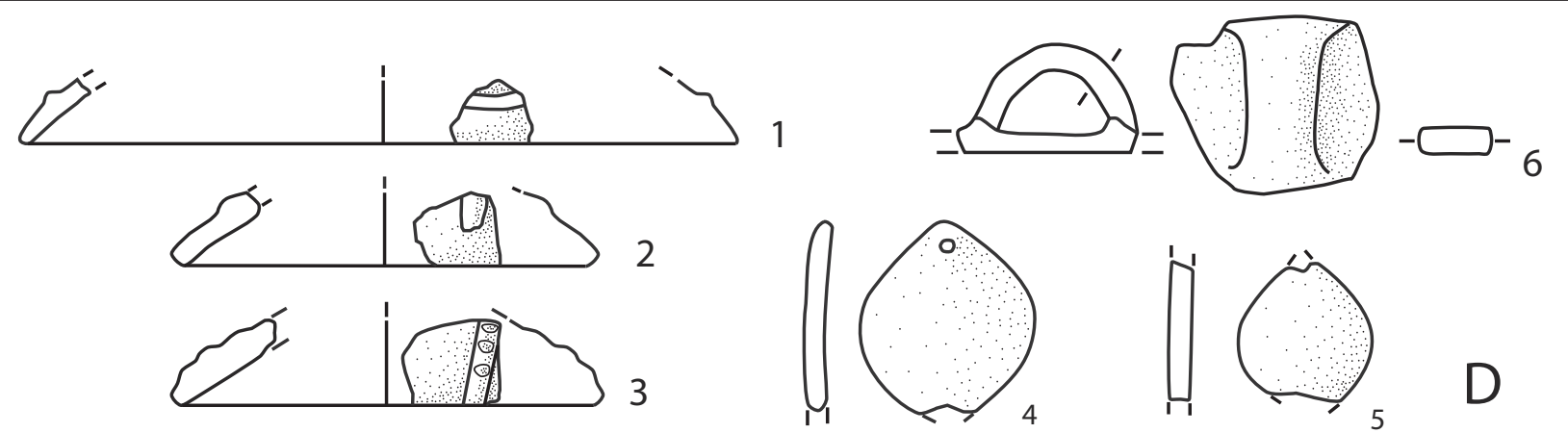

Pl. 9. Treazzano di Monsampolo, pottery. - A: Pithoi (1:5). - B: Jars with a beak (1:4; no. 3: 1:2). - C: Open-shape vessels with an internal strip (1:3). - D: Lids (1:4). 
$S_{1}^{n}-O-1$

A

OD

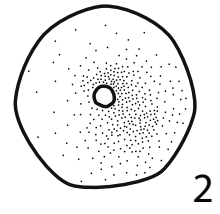

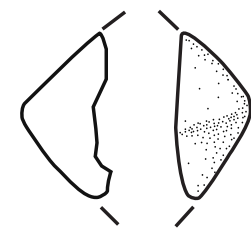

3

B
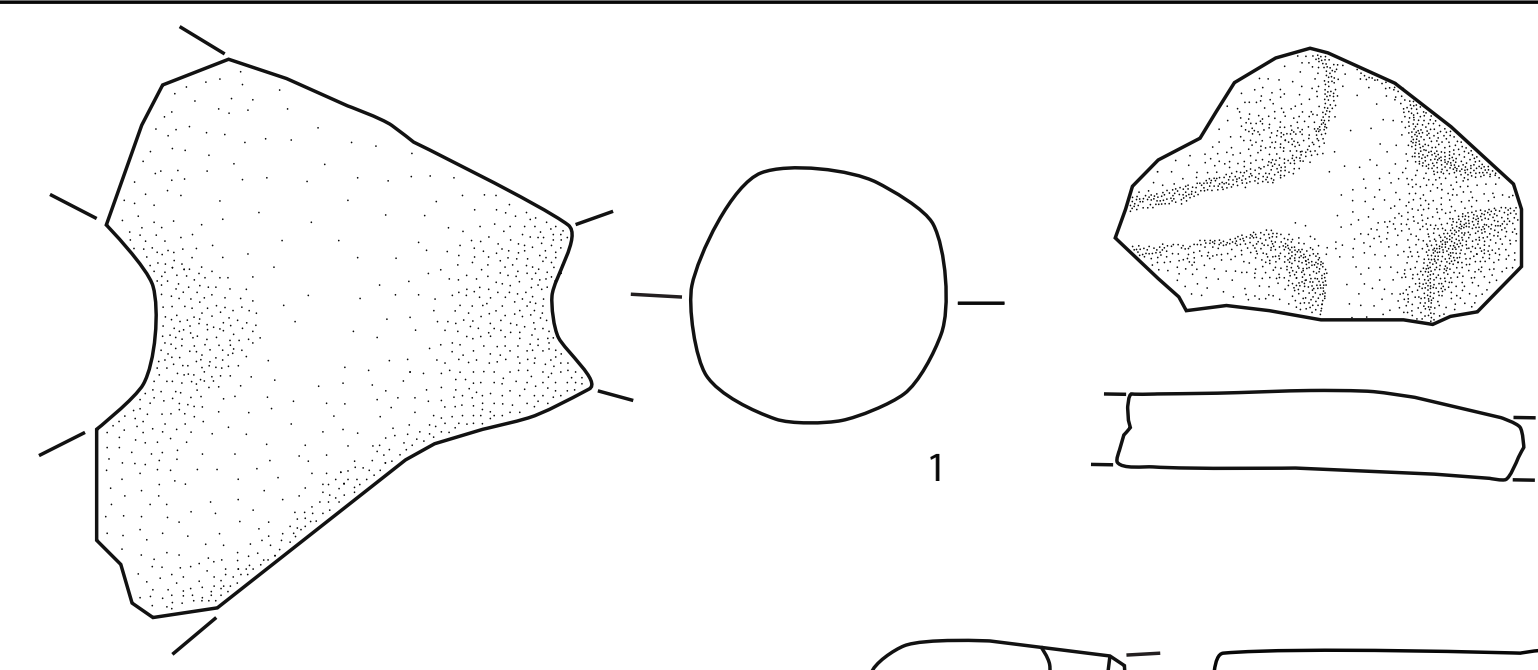

2
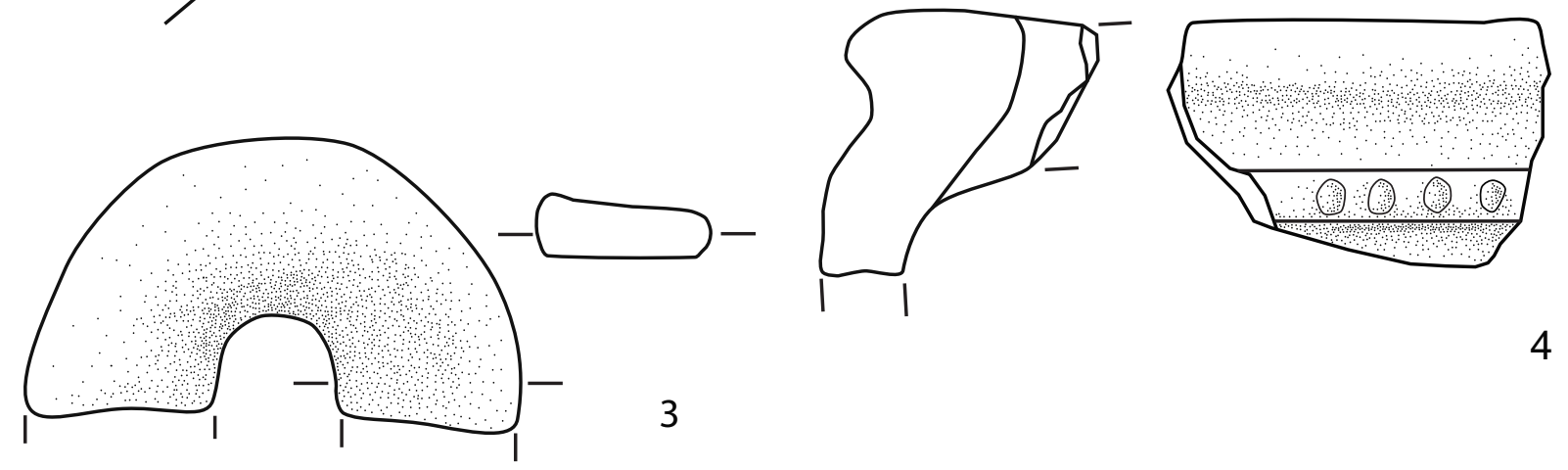

4

C

Pl. 10. Treazzano di Monsampolo, pottery. - A: Zoomorphic figurines (1:2). - B: Spindles (1:2). - C: Stoves (1:3). 


\section{Acknowledgements}

The study presented in this paper is an extract of a master thesis discussed by the author in 2015 at the University of Naples Federico II, Italy. I would like to thank Professor Marco Pacciarelli, tutor of the thesis, for his suggestions about the chronotypological analysis of the materials and the general support provided during all the work, from the very beginning to the conclusions. I also gratefully acknowledge the Soprintendenza per i Beni Archeologici delle Marche, in particular Dr. Nora Lucentini and all the staff of the museum of Ascoli Piceno.

\section{References}

AndreotTi, Zanini 1995-1996

A. Andreot'ti, A. Zanini, L'insediamento di Fossa Nera di Porcari, Rivista di Scienze Preistoriche 47, 1995-1996, 291-330.

ANGLE et al. 1993

M. Angle, C. Caneva, A. M. Conti, L. Costantini, R. Dotttarelli, A. Gianni, C. Giardino, R. E. Jones, C. Persiani, L. VagnetTI, Prime testimonianze micenee nel Lazio, La Parola del Passato 48, 1993, 190-217.

Arancio et al. 2001

M. L. Arancio, V. Buffa, S. Coubrai, A. Curci, I. Damiani, R. E. Jones, A. Tagliacozzo, F. Trucco, L. Vagnetti, Catalogo delle unità stratigrafiche e dei reperti. In: F. TRUCCO, L. VAGNETTI (Eds.), Torre Mordillo 1987-1990: Le Relazioni Egee di una Comunità Protostorica della Sibaritide. Rome 2001, 61-153.

BeLARDELli 2004

C. Belardelli, Coppa Nevigata: collezioni e scavi dagli inizi del 1900. In: D. Cocchi Genick (Ed.), L’Età del Bronzo Recente in Italia. Atti del Congresso Nazionale di Lido di Camaiore, 26-29 ottobre 2000. Viareggio 2004, 526-527.

Bernabò Brea, Cavalier 1980

L. Bernabò Brea, M. Cavalier, Meligunìs Lipàra IV: L’Acropoli di Lipari nella Preistoria. Palermo 1980.

Bernabò Brea, Cremaschi 1995

M. Bernabò Brea, M. Cremaschi, L'indagine archeologica nelle terramare: gli scavi 1991-1993 nel villaggio grande di S. Rosa a Poviglio. In: A. Aspes (Ed.), Modelli Insediativi tra Alpi e Mar Nero dal V al II Millennio a. C. Atti del Simposio Internazionale, Verona - Lazise 1992. Memorie del Mueso Civico di Storia Naturale di Verona 2, sez. C, vol. 4, Verona 1995, 309-323.

BIANCHI 2004

P. A. E. Bianchi, Capanne e spazi domestici del Bronzo Recente avanzato nel villaggio grande della terramara di S. Rosa a Fodico di Poviglio, Rivista di Scienze Preistoriche 54, 2004, 411-485.

Caironi, Guerra, Vaccari 2009

T. Caironi, L. Guerra, B. VAccari, I reperti ceramici dell'abitato di Solarolo tra la fine della media età del Bronzo e l'età del Bronzo Recente, IpoTESI di Preistoria 2/1, 2009, 230-249.

Cardarelli, Pellacani 2004

A. Cardarelli, G. Pellacani, La necropoli di Casinalbo (Formigine, Modena). In: D. Cocchi Genick (Ed.), L'Età del Bronzo Recente in Italia. Atti del Congresso Nazionale di Lido di Camaiore, 26-29 ottobre 2000. Viareggio 2004, 111-120.

Cataldo 1995

L. Cataldo, Il complesso di Fontane di Terlizzi nel museo archeologico di Bari, Taras 15/2, 1995, 275-284.

CATTANi 2009

M. Cattani, L'ansa cilindro-retta come indicatore delle interazioni culturali nel Bronzo Recente, IpoTESI di Preistoria 2/1, 2009, 250-254.
Cazzella, Moscoloni 1988

A. Cazzella, M. Moscoloni, La sequenza dell'età del Bronzo di Coppa Nevigata. In: B. Mundi, A. Gravina (Eds.), Atti dell'Ottavo Convegno Nazionale sulla Preistoria, Protostoria, Storia della Daunia, San Severo, 12-14 dicembre 1986. San Severo 1988, 137-163.

Cazzella, Recchia 2012

A. Cazzella, G. Recchia, Trenta anni di nuove ricerche a Coppa Nevigata. In: A. Cazzella, M. Moscoloni, G. Recchia (Eds.), Coppa Nevigata e l'Area Umida alla Foce del Candelaro. Foggia 2012, 246-318.

Cazzella et al. 2007

A. Cazzella, A. De Dominicis, G. Recchia, C. Ruggini, Elementi di ispirazione egea dai livelli della tarda età del Bronzo del sito di Monteroduni - loc. Paradiso (IS), Rivista Semestrale della Direzione Regionale per i Beni Culturali e Paesaggistici del Molise $1 / 2,2007,35-44$.

Cocchi Genick 1996

D. Cocchi Genick, L’Italia centrale. In: D. Coсchi Genick (Ed.), L'Antica Età del Bronzo in Italia. Atti del Convegno Nazionale, Viareggio, 9-12 gennaio 1995. Florence 1996, 201-203.

DAMIANi 1991

I. Damiani, Facies Archeologica, Facies Culturale: Per una Verifica Critica: Il Caso del Subappenninico. PhD dissertation, University of Rome. Florence 1991.

DAMIANI 2010

I. Damiani, L'Età del Bronzo Recente nell'Italia Centro-Meridionale. Grandi Contesti e Problemi della Protostoria Italiana 12, Borgo San Lorenzo 2010.

Damiani, Morico 1996

I. Damiani, G. Morico, Le ceramiche dell'età del Bronzo di S. Giuliano in Toscanella. In: M. PAcciarelli (Ed.), La Collezione Scarabelli. Preistoria 2, Imola 1996, 316-345.

Danesi, Galluzzi 2009

M. Danesi, V. Galluzzi, Dinamiche di circolazione dei modelli terramaricoli in ambito subappenninico - un caso campione: il sito marchigiano di Conelle di Arcevia. In: M. Silvestrini, T. SABBAtini (Eds.), Fabriano e l'Area Appenninica dell'Alta Valle dell'Esino dall'Età del Bronzo alla Romanizzazione. Atti del Convegno di Studi di Archeologia, Fabriano, 19-21 May 2006. Ancona 2009, 65-79.

De Grossi Mazzorin 1976

J. De Grossi Mazzorin, I materiali dell'età del Bronzo. In: E. De Carolis, M. Pennacchioni, V. D’Ercole, F. Savi, S. Piccarozzi, J. De Grossi Mazzorin, M. Monniello, E. Gubitosi (Eds.), I Materiali della Collezione Allevi Raccolti nel Museo di Offida. Offida 1977, 39-51.

Di Fraia, Grifoni Cremonesi 1996

T. Di Fraia, R. Grifoni Cremonesi, La Grotta di Sant'Angelo sulla Montagna dei Fiori (Teramo): Le Testimonianze dal Neolitico all'Età del Bronzo e il Problema delle Frequentazioni Culturali in Grotta. Rome 1996.

Di GenNaro et al. 2000

F. Di Gennaro, S. Favorito, C. Iaia, F. Trucco, Giacimento dell'età del bronzo alle falde della rupe di Vejano (VT). In: N. Negroni Catacchio (Ed.), L'Etruria tra Italia, Europa e Mondo Mediterraneo. Ricerche e Scavi. Atti del Quarto Incontro di Studi, Manciano, Montalto di Castro-Valentano 12-14 September 1997. Milan 2000, 437-446. 
Di Niro 1991

A. Di NiRo, Il villaggio protostorico di Campomarino, In: S. CAPINI, A. Di Niro (Eds.), Samnium: Archeologia del Molise (Exhibition catalogue, Milan - Campobasso 1991). Rome 1991, 35-49.

FORNARINI 1979

D. Fornarini, Notiziario-Marche, Rivista di Scienze Preistoriche 34, 1979, 314-315.

Fratini 1997

T. Fratini, La Protostoria nella Valle del Pescara. Quaderni del Museo delle Genti d’Abruzzo 25, Pescara 1997.

French 1967

E. B. FrenCH, Pottery from Late Helladic IIIB 1 destruction contexts at Mycenae, Annual of the British School at Athens 60, 1967, 149-193.

Fugazzola Delpino 1976

M. A. Fugazzola Delpino, Testimonianze di Cultura Appenninica nel Lazio. Rome 1976.

FURUMARK 1941

A. Furumark, The Mycenaean Pottery: Analysis and Classification. Stockholm 1941.

GaTTI 2004

D. GatTI, L'Insediamento di Collelongo-“Fond'jò” nel Quadro della Sequenza Culturale Protostorica dell’Abruzzo. Florence 2004.

Gierow 1984

P. G. Gierow, Le fasi preistoriche: dal Neolitico al Bronzo Recente. In: S. Forsberg, B. E. Thomasson (Eds.), San Giovenale: Materiali e Problemi. Atti del Simposio all'Istituto Svedese di Studi Classici a Roma, 6 April 1983. Stockholm 1984, 9-17.

Giorgi, LuCENTINI 2007

E. Giorgi, N. Lucentini, Archeologia nella valle del Tronto. In: E. Giorgi, E. Vecchietti, J. Bogdani (Eds.), Groma 1: Archeologia tra Piceno, Dalmazia ed Epiro. Bologna 2007, 9-17.

Gonzalez Muro, Maini, Mazzarri 2010

X. Gonzalez Muro, E. Maini, L. Mazzarri, L'abitato dell'età del bronzo recente di Meldola (FC), IpoTESI di Preistoria 3/1, $75-114$.

IALONGO 2007

N. IAlongo, Il Fucino nella Protostoria. Borgo San Lorenzo 2007.

JONES et al. 2014

R. E. Jones, S. T. Levi, M. BetTelli, L. VagnetTi, Italo-Mycenaean Pottery: The Archaeological and Archaeometric Dimensions. Rome 2014.

KARDAMAKI 2015

E. Kardamaki, Conclusions from the new deposit at the western staircase terrace at Tiryns. In: A. L. Schallin, I. Tournavitou (Eds.), Mycenaeans up to date: The Archaeology of the North Eastern Peloponnese Current Concepts and New Directions. Acta Instituti Atheniensis Regni Sueciae 4, 56, Stockholm 2015, 79-97.

Leopardi, De Pompeis 1980

G. B. Leopardi, C. De Pompeis, Un Villaggio dell'Età del Bronzo Finale a Madonna degli Angeli di Tocco Casauria (Pescara). Quaderni del Museo delle Tradizioni Popolari Abruzzesi 3, Pescara 1980.

LOLLINI 1959

D. Lollini, Appenninici, Protovillanoviani e Piceni nella realtà culturale delle Marche. In: Atti del Secondo Convegno di Studi Etruschi, Ancona, 19-22 June 1958. Florence 1959, 45-60.
LOLLINI 1979

D. Lollini, Il bronzo finale nelle Marche, Rivista di Scienze Preistoriche 34, 1979, 179-215.

LOLLINI 1982

D. Lollini, Treazzano di Monsampolo (Castel di Lama, Ascoli Piceno). In: L. VagnetTi (Ed.), Magna Grecia e Mondo Miceneo: Nuovi Documenti. Atti XXII Convegno di Studi sulla Magna Grecia, Taranto, 7-11 October 1982. Naples 1982, 197-199.

Lo PORTo 1997

F. G. Lo Porto, Kanysion 1: la necropoli protostorica a cremazione di contrada Pozzillo, Studi di Antichità 10, 1997, 71-118.

LUCENTINI 1987

N. Lucentini, Note per la viabilità nell'ascolano meridionale in età preistorica. In: Le strade nelle Marche: Il Problema nel Tempo. Atti del Convegno, Fano, Fabriano, Pesaro, Ancona, 11-14 ottobre 1984. Ancona 1984, 437-494.

LUCENTINI 1995

N. LuCENTini, Il territorio di San Benedetto e aree limitrofe nella pre-protostoria. In: M. PACI (Ed.), Archeologia nell'Area del Basso Tronto. Convegno di Studi, San Benedetto del Tronto, 3 October 1993. Picus Suppl. 4, Tivoli 1995, 17-48.

Macchiarola 1987

I. Macchiarola, La Ceramica Appenninica Decorata. Rome 1987. MANDOLESI 1993

A. Mandolesi, Primi dati sul popolamento in età protostorica della valle del torrente Arrone. In: N. Negroni Catacchio (Ed.), Preistoria e Protostoria in Etruria. Atti del I Incontro di Studi, Farnese-Saturnia, 17-19 May 1991. Milan 1993, 245-252.

Massi Pasi, Stoppioni 1988

M. Massi Pasi, L. Stoppioni, Case Missiroli. In: L. Prati (Ed.), Flumen Aquaeductus: Nuove Scoperte Archeologiche dagli Scavi per l'Acquedotto della Romagna. Bologna 1988, 147-168.

Mieli, D’Ercole, Cosentino 2003

G. Mieli, V. D’Ercole, S. Cosentino, Alcune riflessioni sulle necropoli protostoriche dell'Abruzzo interno appenninico: il caso di Bazzano a l'Aquila. In: Preistoria e Protostoria dell'Abruzzo. Atti della XXXVI Riunione Scientifica, Chieti, Celano, 27-30 September 2001. Florence 2003, 533-547.

Moscoloni, Danesi, Galluzzi 2007

M. Moscoloni, M. Danesi, V. Galluzzi, L'insediamento subappenninico di Conelle di Arcevia, Origini 29, 2007, 75-118.

MounTJOy 1999

P. A. MounTJoy, Regional Mycenaean Decorated Pottery. Rahden/ Westf. 1999.

Pacciarelli 1979

M. Pacciarelli, Topografia dell'insediamento dell'età del bronzo recente nel Lazio. In: S. Quilici Gigli (Ed.), Archeologia Laziale II: Secondo Incontro di Studio del Comitato per l'Archeologia Laziale. Quaderni di Archeologia Etrusco-Italica 3, Rome 1979, 161-170.

PASQUini 2005

M. Pasquini, L'industria su corno di Moscosi di Cingoli: forme principali e loro diffusione. In: Preistoria e Protostoria delle Marche. Atti della XXXVIII Riunione Scientifica, Portonovo, Abbadia di Fiastra, 1-5 October 2003. Florence 2005, 985-991.

Pennacchioni, Persiani 1982

M. Pennacchioni, C. Persiani, L’insediamento preistorico della Montarana. In: Atti del IV Convegno dei Gruppi Archeologici del Lazio, Rieti, 8-9 December 1979. Rome 1982, 17-22. 
Percossi, Pignocchi, Sabbatini 2005

E. Percossi, G. Pignocchi, T. Sabbatini, Un sito dell'età del bronzo a Cisterna di Tolentino. In: Preistoria e Protostoria delle Marche. Atti della XXXVIII Riunione Scientifica, Portonovo, Abbadia di Fiastra, 1-5 October 2003. Florence 2005, 659-678.

Peroni 1959

R. Peroni, Per una Definizione dell'Aspetto Culturale "Subappenninico” come Fase Cronologica a sé Stante. Memorie dell’Accademia Nazionale dei Lincei 9/1, Rome 1959.

Peroni 1989

R. Peroni, Protostoria dell'Italia Continentale: La Penisola Italiana nelle Età del Bronzo e del Ferro. Popoli e Civiltà dell'Italia Antica 9, Rome 1989.

Pettazzoni 1916

R. Pettazzoni, Stazioni Preistoriche della Provincia di Bologna. Monumenti Antichi dei Lincei XXIV, Rome 1916.

Pignocchi, Silvestrini 2015

G. Pignocchi, M. Silvestrini, Le Marche e l'area terramaricola: elementi di confronto nella ceramica da Moscosi di Cingoli e Cisterna di Tolentino (Macerata). In: G. Leonardi, V. Tiné (Eds.), Preistoria e Protostoria del Veneto. Florence 2015, 735740.

Poggiani Keller 1999

R. Poggiani Keller, Scarceta di Manciano (GR): Un Centro Abitativo e Artigianale dell'Età del Bronzo sulle Rive del Fiora. Manciano 1999.

Polletti 2000

M. Polletti, Presenze protostoriche a Castel Trosino. In: G. Paci, E. Catani (Eds.), La Salaria in Età Antica. Atti del Convegno di Studi, Ascoli Piceno, Offida, Rieti, 2-4 October 1997. Rome 2000, 371-386.

Provenzano 1997

N. Provenzano, Produzione in osso e corno delle terramare emiliane. In: M. Bernabò Brea, A. Cardarelli, M. Cremaschi (Eds.), Le Terramare: La Più Antica Civiltà Padana. Milan 1997, 524-544.

Puglisi 1982

S. Puglisi, Coppa Nevigata (Manfredonia-Foggia). In: L. VAGneTti (Ed.), Magna Grecia e Mondo Miceneo: Nuovi Documenti. Atti XXII Convegno di Studi sulla Magna Grecia, Taranto, 7-11 October 1982. Naples 1982, 45-52.

RELLINI 1932

U. Rellini, Le Stazioni Enee delle Marche di Fase Seriore e la Civiltà Italica. Monumenti Antichi dei Lincei XXXIV, Rome 1932.

SabBatini, Silvestrini 2005

T. Sabbatini, M. Silvestrini, Piano di Forte Marcosa, Moscosi di Cingoli: un sito puristratificato dell'Appennino marchigiano: le fasi del Bronzo Recente. In: Preistoria e Protostoria delle Marche. Atti della XXXVIII Riunione Scientifica, Portonovo, Abbadia di Fiastra, 1-5 October 2003. Florence 2005, 639-657.

Sabbatini, Silvestrini, Milazzo 2009

T. Sabbatini, M. Silvestrini, F. Milazzo, Moscosi di Cingoli (Macerata) e l'area centroadriatica nella tarda età del bronzo: aspetti di carattere internazionale e di koinè metallurgica fra Egeo e area alpina. In: P. CAssola Guida, E. Borgna (Eds.), Dall’Egeo all'Adriatico: Organizzazioni Sociali, Modi di Scambio e Interazione in Età Postpalaziale (XII-XI secolo a. C.) / From the Aegean to the Adriatic: Social Organizations, Modes of Exchange and Interaction in Postpalatial Times $\left(12^{\text {th }}-11^{\text {th }}\right.$ c. BC). Atti del
Seminario Internazionale, Udine, 1-2 December 2006. Rome 2009, 235-256.

SALZANI 1994

L. Salzani, L'Abitato e la Necropoli di Sabbionara a Veronella: Prime Ricerche. Cologna Veneta 1994.

SALZANI 2014

L. SAlzani, Pianura veronese: segnalazione di nuovi siti protostorici, Notizie di Archeologia del Veneto 3, 2014, 112-118.

SHELTON 2007

K. S. Shelton, Foot soldiers and cannon fodder: the underrepresented majority of the Mycenaean civilization. In: S. P. MorRIS, R. LAfFineur (Eds.), Epos: Reconsidering Greek Epic and Aegean Bronze Age Archaeology. Proceedings of the $11^{\text {th }}$ International Aegean Conference / $11^{\mathrm{e}}$ Rencontre égéenne internationale, Los Angeles, UCLA - The J. Paul Getty Villa, 20-23 April 2006. Aegaeum 28, Liège 2007, 169-175.

Silvestrini, Pignocchi 1997

M. Silvestrini, G. Pignocchi, The Bronze Age settlement of Moscosi-Cingoli (MC), Preistoria Alpina 33, 1997, 155-160.

Thomas 2005

M. Thomas, A deposit of Late Helladic IIIB1 pottery from Tsoungiza, Hesperia 74, 2005, 451-573.

Trucco, VAgnetTi 2001

F. Trucco, L. VagnetTi, Torre Mordillo 1987-1990: Le Relazioni Egee di una Comunità Protostorica della Sibaritide. Incunabula Graeca CI, Rome 2001.

VAGNETTI et al. 2006

L. Vagnetti, E. Percossi, M. Silvestrini, T. Sabbatini, R. E. JoNES, S. T. LEvi, Ceramiche egeo-micenee dalle Marche: analisi archeometriche e inquadramento preliminare dei risultati. In: Materie Prime e Scambi nella Preistoria Italiana. Atti della XXXIX Riunione Scientifica, Florence, 25-27 November 2004. Florence 2006, 1159-1172.

VIGLIARDI 1968

A. Vigliardi, Una stazione della tarda età del bronzo a S. Maria in Castello (Tredozio, prov. Di Forlì), Archivio per l'Antropologia e l'Etnologia XCVIII, 1968, 1-48.

VIKATOU 2001

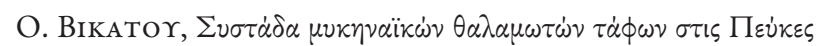

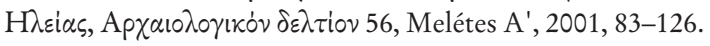

VOIGTLÄNDER 2003

W. Voigtländer, Die Palastkeramik aus Tiryns. Tiryns - Forschungen und Berichte 10, Mainz 2003.

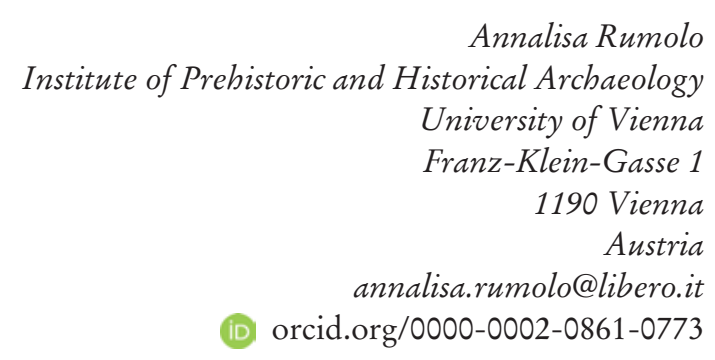

